\title{
Reactivity patterns of protonated Compound II and Compound I of Cytochrome P450: What is the better oxidant?
}

\author{
Xiao-Xi Li, ${ }^{[a]}$ Verònica Postils, ${ }^{[b, c]}$ Wei Sun, ${ }^{[a]}$ Abayomi S. Faponle, ${ }^{[c]}$ Miquel Solà, ${ }^{[b]}$ Yong Wang, ${ }^{*[a]}$ \\ Wonwoo Nam, ${ }^{*[d]}$ and Sam P. de Visser ${ }^{*[c]}$
}

\begin{abstract}
The cytochromes P450 are versatile enzymes in human physiology that perform substrate hydroxylation reactions extremely efficient. In this work, we present results of a computational study on the reactivity patterns of Compound I, Compound II and protonated Compound II with model substrates and addresses the question, which of those is the most effective oxidant. All calculations, regardless of the substrate, implicate that Compound $\mathrm{I}$ is the superior oxidant of the three. However, Compound II and protonated Compound II are found to react with free energies of activation that are only a few $\mathrm{kcal} \mathrm{mol}^{-1}$ higher in energy than those obtained with Compound I. Therefore, Compound II and protonated Compound II should be able to react with aliphatic groups with moderate $\mathrm{C}-\mathrm{H}$ bond strengths. We have analyzed all results in detail and give electronic, thermochemical, valence bond and molecular orbital rationalizations on the reactivity differences and explain experimental product distributions. Overall, the work implies that alternative oxidants could operate alongside Compound I in complex reaction mechanisms of enzymatic and synthetic iron porphyrin complexes.
\end{abstract}

\section{Introduction}

One of the most extensively studied enzyme classes in chemical biology and biological chemistry are the cytochromes P450 (P450s). The P450s appear in virtually all forms of life and catalyse important monoxygenation reactions with functions ranging from biodegradation to biosynthesis. ${ }^{[1]}$ For instance, in the human liver, the P450s are involved in drug metabolism reactions but also the biosynthesis of, e.g., estrogen. ${ }^{[2,3]}$ Due to their diverse functions, the P450s are highly versatile in structure but, despite this contain conserved structural features as

[a] X.-X. Li, W. Sun and Prof. Y. Wang

State Key Laboratory for Oxo Synthesis and Selective Oxidation, Suzhou Research Institute of LICP, Lanzhou Institute of Chemical

Physics (LICP)

Chinese Academy of Sciences, Lanzhou 730000, P.R. China

E-mail: wangyong@licp.cas.cn

[b] Miss V. Postils and Prof. M. Solà

Institut de Química Computacional i Catàlisi (IQCC) and Department de Química, Universitat de Girona

Campus de Montilivi, 17003 Girona, Catalonia, Spain

[c] Miss V. Postils, Dr A.S. Faponle and Dr S.P. de Visser

The Manchester Institute of Biotechnology and School of Chemical

Engineering and Analytical Science, The University of Manchester

131 Princess Street, Manchester M1 7DN, United Kingdom

Email: sam.devisser@manchester.ac.uk

[d] Prof. W. Nam

Department of Chemistry and Nano Science, Ewha Womans

University

Seoul 03760, Korea

Email:wwnam@ewha.ac.kr

Supporting information for this article is given via a link at the end of the document. highlighted in the crystal structure coordinates of thousands of isozymes that have been reported. ${ }^{[4]}$ Generally, the P450s have a central iron-heme group that is connected to the protein through a linkage of the central iron atom with the thiolate group of a cysteinate residue (the axial ligand). Figure 1 gives an example of the active site of a typical P450 liver isozyme, namely from $\mathrm{P}^{4} 50_{2 \mathrm{D} 6}$ as taken from the $4 \mathrm{WNT}$ protein databank (pdb) file. ${ }^{[5]}$

In Figure 1, the enzyme substrate (the drug molecule ajmalicine) is bound in a cleft on the distal site of the heme, but does not form a covalent bond with the heme. On the distal site of the heme, molecular oxygen binds, which in the catalytic cycle using two reduction and two protonation equivalents is converted into an iron(IV)-oxo heme cation radical active species, called Compound I (Cpdl). ${ }^{[6]}$ Cpdl is characterized as a triradical species with unpaired electrons in two $\mathrm{FeO}$ type orbitals $\left(\pi^{*} x z\right.$ and $\pi^{*} y z$ ) and a heme-based radical (in $\left.a_{2 u}\right){ }^{[7]}$ It is highly reactive in oxygen atom transfer reactions to substrates and often gives products associated with aliphatic hydroxylation. It has been argued for a long time that $\mathrm{Cpdl}$ is the sole oxidant of P450 enzymes and typically reacts with aliphatic groups by hydrogen atom abstraction (HAT), followed by a fast radical rebound to form alcohol products. ${ }^{[8]}$

Spectroscopic characterization of Cpdl by Rittle and Green in combination with reaction rate measurements for hydrogen and deuterium substituted substrates gave evidence of its reactivity patterns and established $\mathrm{Cpdl}$ as the active oxidant of P450 enzymes..$^{[9]}$ Computational modelling further supported experimental observation and identified Cpdl as a versatile oxidant involved in a range of reactivity patterns with substrates that also includes aromatic hydroxylation, sulfoxidation, olefin epoxidation, $\mathrm{N}$-dealkylation and dehydrogenation. ${ }^{[10]}$

In contrast to the P450s, in heme peroxidases the catalytic cycle does not stop with $\mathrm{Cpdl}$, but through a one-electron reduction it is converted into Compound II (Cpdll) prior to substrate activation, i.e. iron(IV)-oxo heme, whereby the extra electron has filled the $\mathrm{a}_{2 u}$ orbital with a second electron. ${ }^{[11]}$ Furthermore, some studies have suggested Cpdll to be protonated, i.e. iron(IV)-hydroxo heme, resulting from a hydrogen atom abstraction by Cpdl. ${ }^{[12]}$ As such, there is controversy regarding the actual active species in peroxidases, which may have relevance to P450 chemistry as well. Thus, $\mathrm{P} 450$ s with excess reduction partner or under acidic conditions, may be in a situation where the catalytic cycle does not stop with Cpdl, but quickly proceeds to Cpdll or protonated Cpdll instead. 

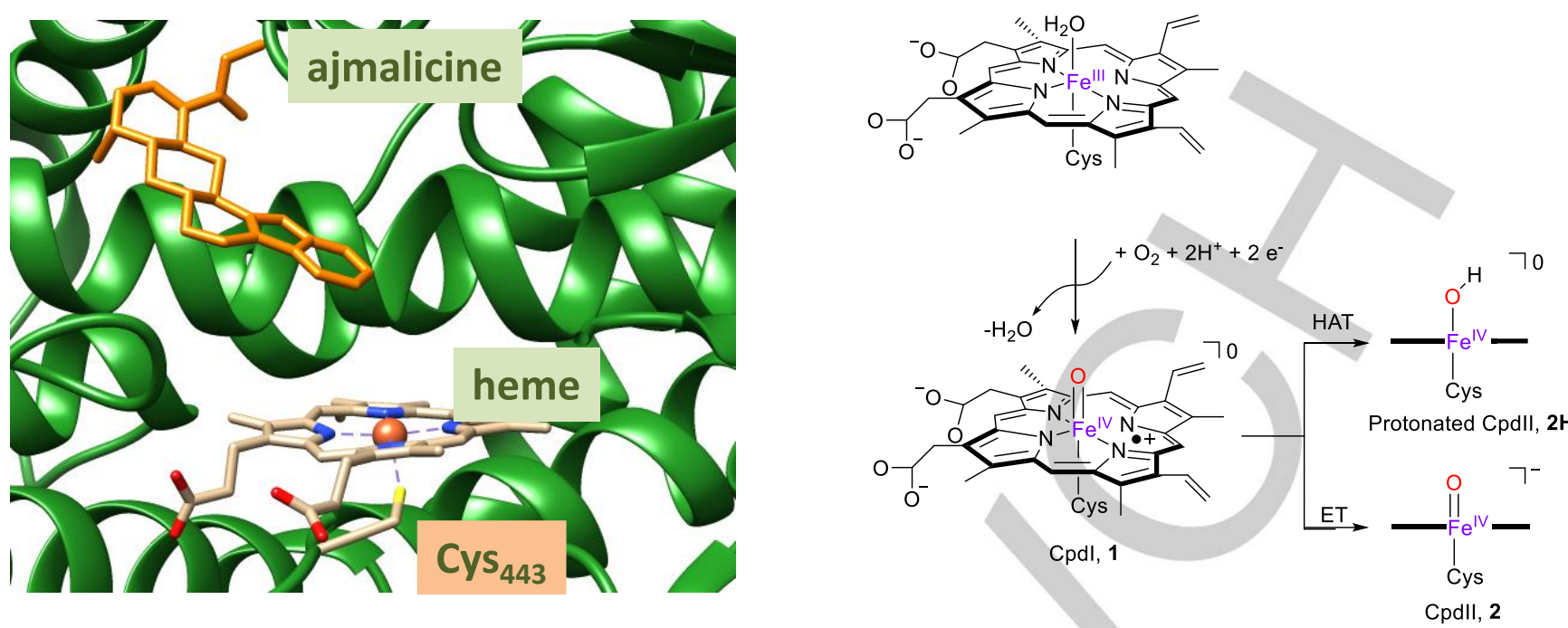

Figure 1. Active site structure of a typical P450 isozyme with substrate (ajmalicine) bound (left). On the right-hand-side the possible reaction channels of Cpdl for electron transfer (ET) and hydrogen atom transfer (HAT) leading to Cpdll and protonated Cpdll, respectively, are also given.

It is, therefore, important to understand the catalytic differences of Cpdl, Cpdll and protonated Cpdll. In particular, either Cpdl (1), Cpdll (2) or protonated Cpdll $\left(2 \mathrm{H}^{+}\right)$(Figure 1) could act as possible oxidants in substrate activation, but little is known on whether they all should be considered as oxidants or not. In order to resolve this controversy we decided to do a detailed computational study into the relative reactivity patterns of Cpdl, Cpdll and protonated Cpdll with model substrates.

As enzymatic studies struggle to characterize and trap these short-lived catalytic cycle intermediates, in many research groups biomimetic model complexes are studied that contain the active site features of the enzyme, but not the protein environment. ${ }^{[13]}$ For instance, in several groups, models of Cpdl and Cpdll have been trapped and characterized. Using a biomimetic iron meso-tetramesitylporphyrin (TMP), van Eldik and co-workers ${ }^{[14]}$ managed to study the properties and reactivities of Cpdl and Cpdll models. In particular, they investigated the reactivity of both species with a selection of substrates and found Cpdll to be the better oxidant in hydride transfer reactions, whereas $\mathrm{C}-\mathrm{H}$ abstraction reactions and $\mathrm{C}=\mathrm{C}$ epoxidation reactions were performed faster by $\mathrm{Cpdl}$ instead. These studies supported early work of Groves and co-workers ${ }^{[15]}$ on cis- $\beta$ methylstyrene epoxidation by $\left[\mathrm{Fe}^{\mathrm{IV}}(\mathrm{O})(\mathrm{TMP})\right]^{+}$models that gave higher reactivity of Cpdl than Cpdll. Interestingly, the studies implicated $\mathrm{Cpdl}$ to react stereospecifically to form dominant cisepoxide products in a ratio of cis to trans of 11.3 , whereas a ratio of 1.0 was observed in the reaction of this substrate with Cpdll. Nam et al[16] studied several meso-substituted ironporphyrin complexes and generated the Cpdl and Cpdll structures. They found efficient reactivity by Cpdll in hydride abstraction reactions of substrates with weak $\mathrm{C}-\mathrm{H}$ bonds, such as 9,10-dihydroanthracene and 10-methyl-9,10-dihydroacridine. More recently, van Eldik and co-workers ${ }^{[17]}$ established the reactivity differences of $\mathrm{Cpdl}$ and $\mathrm{Cpdll}$ using iron-porphyrin models and found that the reaction with Cpdl is entropically controlled, whereas the one with Cpdll is enthalpically controlled. Clearly, biomimetic model complexes reveal that both $\mathrm{Cpdl}$ and Cpdll should be potent oxidants of substrate hydroxylation reactions, but it is unclear what the origins of these reactivity differences are and how it could relate to enzymatic catalysis. It may very well be that in an enzymatic arrangement with a nearby reduction partner, Cpdl is reduced to Cpdll prior to its reaction with substrates. As the reactivity of these two oxidants is not well understood, we decided to do a detailed computational investigation into the reactivity of Cpdl, Cpdll and protonated Cpdll with a selection of model substrates. The studies give detailed insights into the potential catalytic properties of Cpdll and its protonated form and highlight that if they are formed; they can still turnover substrates albeit at much slower rates.

\section{Results}

\section{Reactivity of Cpdl (1)}

Our initial studies were focused on the reactivity and, in particular, hydrogen atom abstraction ability of Cpdl (1). Figure 2 displays the calculated enthalpy at $0 \mathrm{~K}\left(\Delta \mathrm{E}+\mathrm{ZPE}+\mathrm{E}_{\text {solv }}\right)$ landscape of cyclohexane $(\mathrm{CH})$ and ethylbenzene (EB) hydroxylation by ${ }^{2,4}\left[\mathrm{Fe}^{\mathrm{IV}}(\mathrm{O})\left(\mathrm{Por}^{+*}\right) \mathrm{SH}\right]$ or ${ }^{2,4} \mathbf{1}$. Raw data are given in the Supporting Information Tables S6 - S9. We started the work from the reactants, ${ }^{2,4} \mathbf{1}$, which, as before, ${ }^{[18]}$ have Cpdl described as a triradical system with $\delta_{x 2-y 2}{ }^{2} \pi^{*}{ }_{x z}^{1} \pi^{*}{ }_{y z}{ }^{1} \quad a_{2 u}{ }^{1}$ configuration with an overall doublet or quartet spin. These two states are degenerate and are calculated within $1 \mathrm{kcal} \mathrm{mol}^{-1}$ of energy. 


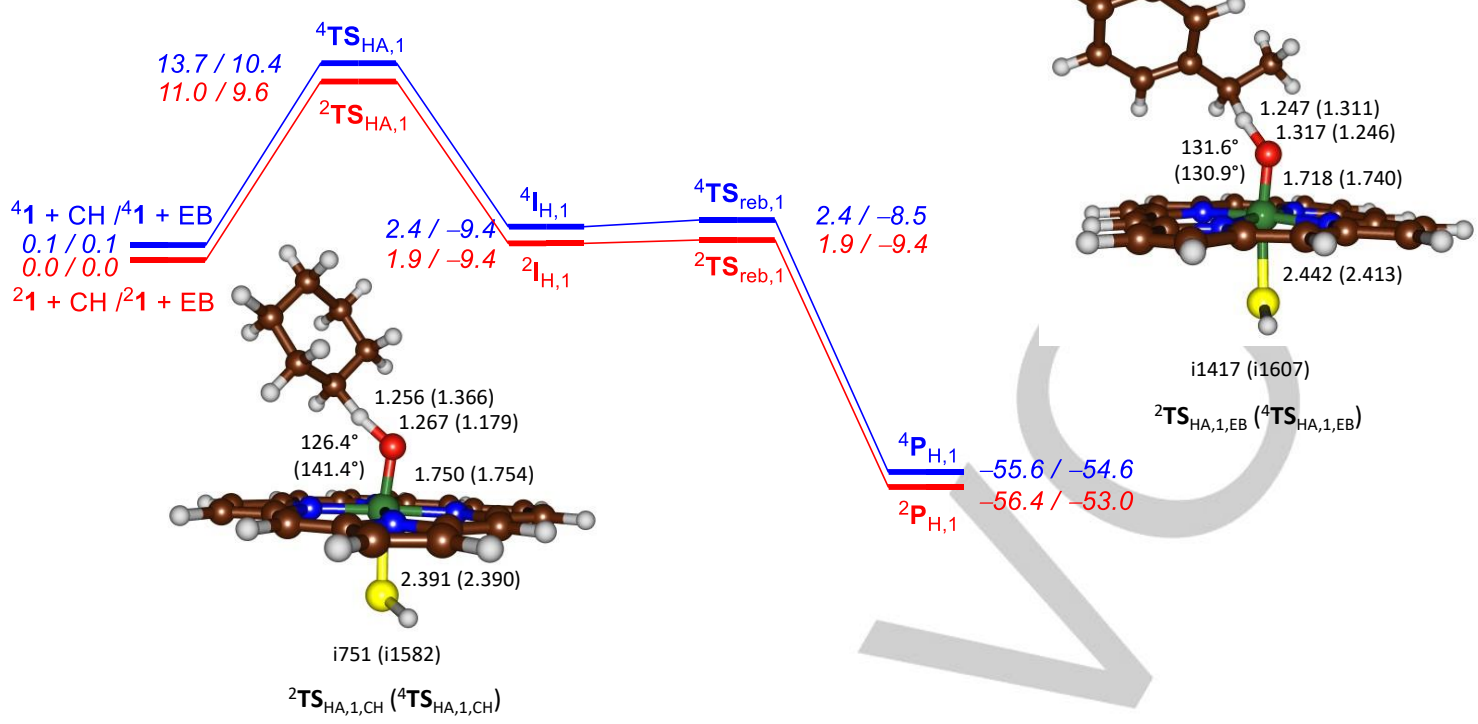

Figure 2. UB3LYP/BS2//UB3LYP/BS1 calculated potential energy landscape of cyclohexane $(\mathrm{CH})$ and ethylbenzene (EB) hydroxylation by ${ }^{2,4} \mathbf{1}$. Enthalpies (in $\mathrm{kcal} \mathrm{mol}^{-1}$ ) are calculated relative to isolated reactants and use UB3LYP/BS2 energies with zero-point and solvent corrections. Optimized geometries of the transition states give bond lengths in angstroms and the imaginary frequency in $\mathrm{cm}^{-1}$.

In a reaction with aliphatic substrates a hydrogen atom abstraction takes place via a transition state $\left(\mathbf{T S}_{\mathrm{HA}, 1}\right)$ leading to a radical intermediate $\left(\mathbf{I}_{\mathrm{H}, 1}\right)$ consisting of $\left[\mathrm{Fe}{ }^{\mathrm{IV}}(\mathrm{OH})(\mathrm{Por}) \mathrm{SH}\right]$ and a radical substrate rest-group. ${ }^{[19]}$ The generation of a benzylic radical stabilized by resonance explains the exothermicity of the $\mathbf{I}_{\mathrm{H}, 1}$ formation process in the EB hydroxylation. ${ }^{[20]}$ In the course of this hydrogen atom abstraction, an electron is transferred into the oxidant set of orbitals and fills the $a_{2 u}$ orbital with a second electron in both the doublet and quartet spin states. As such, the doublet and quartet spin potential energy surfaces are close in energy along the pathway from reactants to radical intermediates. In a subsequent step the radical rebounds the $\mathrm{OH}$ group to form the alcohol product complexes $\left(\mathbf{P}_{\mathrm{H}, 1}\right)$.

Technically, the radical intermediates and product complexes should be separated by a rebound transition state ( $\left.\mathbf{T S}_{\mathrm{reb}, 1}\right)$, however, in all cases these barriers were negligible and we were only able to properly optimize a rebound transition state for quartet spin with ethylbenzene as a substrate $\left({ }^{4} \mathbf{T S}_{\mathrm{reb}, 1, \mathrm{~EB}}=\right.$ $0.9 \mathrm{kcal} \mathrm{mol}^{-1}$ above the radical intermediate). Since, all rebound barriers on all spin state surfaces are small, this implies that the radical intermediates will have a very short lifetime and lead to products rapidly. Due to the short lifetime of the radical intermediates, no rearrangement or isomerizations will take place and hence the reaction is expected to give stereochemical retention of products. ${ }^{[21]}$ Indeed, Groves and co-workers studied the reaction of cis- $\beta$-methylstyrene epoxidation by a Cpdl model and found retention of stereochemistry. ${ }^{[15]}$ As such, the calculated potential energy profile is in good agreement with the product distributions obtained experimentally. As follows from Figure 2, the reaction takes place via a rate determining hydrogen atom abstraction barrier with barrier heights of 9.6 (10.4) kcal mol${ }^{-1}$ for ethylbenzene and 11.0 (13.7) $\mathrm{kcal} \mathrm{mol}^{-1}$ for cyclohexane on the doublet (quartet) spin states. These values as well as the optimized geometries shown in Figure 2 are in good agreement with those calculated previously. ${ }^{[22]}$

Geometrically, most transition states are central with similar $\mathrm{C}-\mathrm{H}$ and $\mathrm{O}-\mathrm{H}$ distances, although the ${ }^{4} \mathbf{T} \mathbf{S}_{\mathrm{HA}, 1, \mathrm{CH}}$ structure has a long $\mathrm{C}-\mathrm{H}$ bond and is, therefore, more product-like. All hydrogen atom abstraction transition states are characterized by a single imaginary mode of i751 ( $\left.{ }^{2} \mathbf{T S}_{\mathrm{HA}, 1, \mathrm{CH}}\right)-i 1607\left({ }^{4} \mathbf{T S}_{\mathrm{HA}, 1, \mathrm{~EB}}\right) \mathrm{cm}^{-1}$. As a result, the potential energy surface around the transition state will be sharp and narrow and sensitive to, e.g. isotopic substitution of hydrogen by deuterium. 


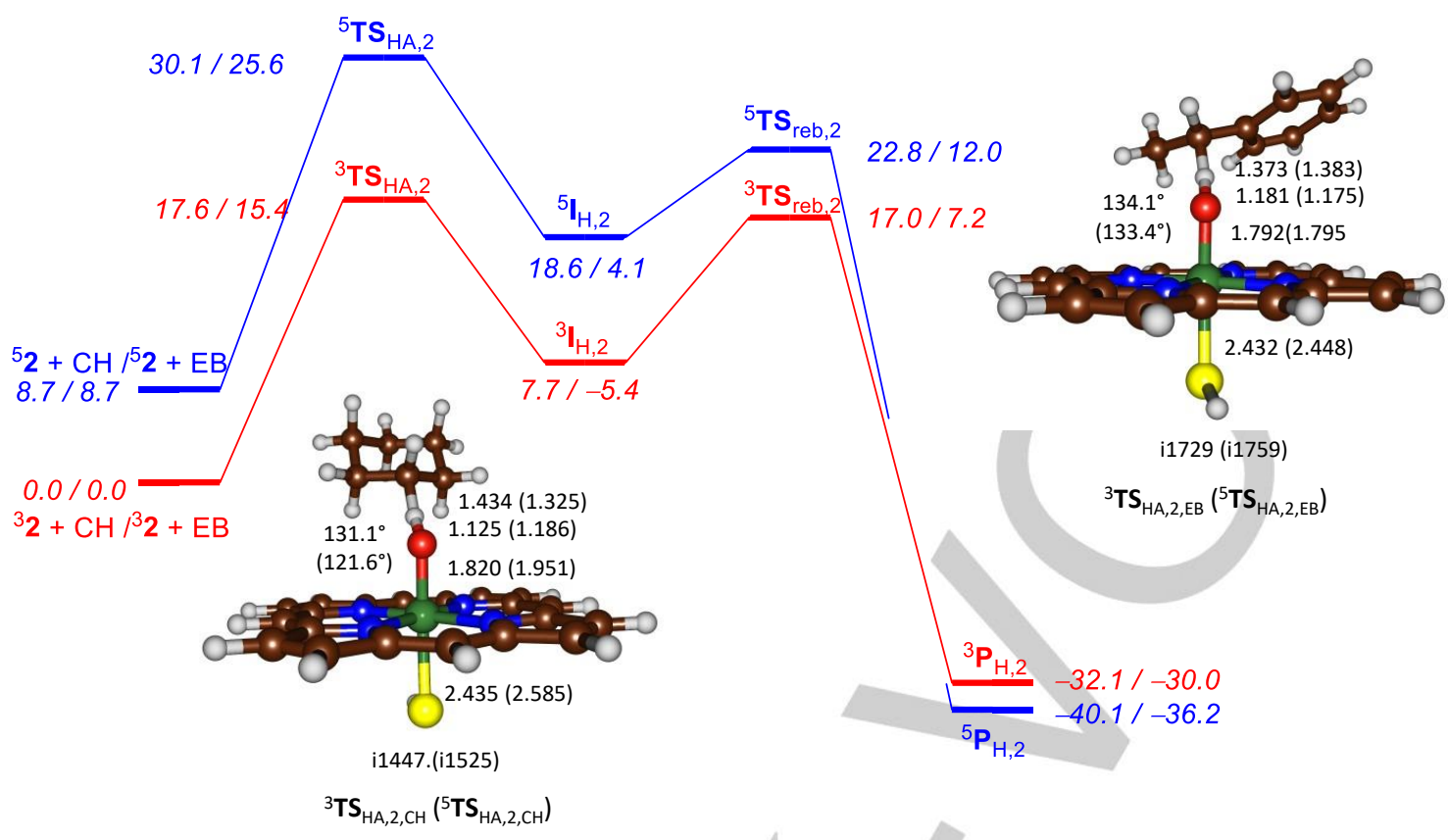

Figure 3. UB3LYP/BS2//UB3LYP/BS1 calculated potential energy landscape of cyclohexane (CH) and ethylbenzene (EB) hydroxylation by ${ }^{3,5}$. Enthalpies (in $\mathrm{kcal} \mathrm{mol}^{-1}$ ) are calculated relative to isolated reactants and use UB3LYP/BS2 energies with zero-point and solvent corrections. Optimized geometries of the transition states give bond lengths in angstroms and the imaginary frequency in $\mathrm{cm}^{-1}$.

\section{Reactivity of CpdII (2)}

Subsequently, we investigated the reactivity patterns of Cpdll models of P450 $(3,52)$ in the triplet and quintet spin states with cyclohexane and ethylbenzene as substrates. Figure 3 displays the calculated enthalpy profile as well as the optimized geometries of the hydrogen atom abstraction transition states, whereas raw data and the remaining structures are given in the Supporting Information Tables S10 - S13 and Figures S6 - S8. Similarly to the reaction described above for Cpdl, the mechanism is stepwise via a radical intermediate $\left({ }^{3,5} \mathbf{I}_{\mathrm{H}, 2}\right)$ leading to the alcohol product complexes $\left({ }^{3,5} \mathbf{P}_{\mathrm{H}, 2}\right)$ in a strongly exothermic process. The radical intermediates are separated from reactants via a hydrogen atom abstraction barrier $\left({ }^{3,5} \mathbf{T S}_{\mathrm{HA}, 2)}\right.$ and from products via a rebound transition state $\left({ }^{3,5} \mathbf{T S}_{\mathrm{reb}, 2}\right)$. Cpdll, in contrast to Cpdl, has well separated spin states (>8

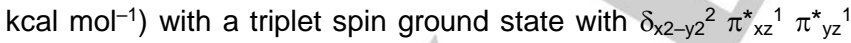
$\mathrm{a}_{2 \mathrm{u}^{2}}$ configuration. The quintet spin state with $\delta_{\mathrm{x} 2-\mathrm{y} 2}{ }^{1} \pi^{*}{ }_{\mathrm{xz}}{ }^{1} \pi^{*} \mathrm{yz}{ }^{1}$ $\sigma_{x y}^{*}{ }^{1} \mathrm{a}_{2 u^{2}}$ configuration is found to be $8.7 \mathrm{kcal} \mathrm{mol}^{-1}$ higher in energy in the reactants. The triplet spin state stays as the ground state along the reaction mechanism and only in the product configuration the quintet spin becomes more stable.

In contrast to the mechanism in Figure 2, the Cpdll mechanism gives distinct rebound barriers on all spin states. On the triplet spin states, rebound barriers are of the order of 10 $\mathrm{kcal} \mathrm{mol}{ }^{-1}$. A barrier of this magnitude will imply that the radical intermediate has a finite lifetime and during its lifetime can undergo rearrangement or structural isomerizations leading to stereochemical scrambling. Indeed, the work of Groves et al[15] showed that a mixture of products was obtained from a reaction of a Cpdll model with cis- $\beta$-methylstyrene, in agreement with the high rebound barriers seen in Figure 3 . The calculations are also in agreement with earlier DFT studies of Rosa and Ricciardi ${ }^{[23]}$ that found Cpdll to react on a dominant triplet spin pathway with similar barriers for the hydrogen atom abstraction and radical rebound processes.

The rate determining step in the reaction mechanism of Cpdll with substrates is the initial hydrogen atom abstraction, and, hence, the reaction still will be sensitive to isotopic substitution of hydrogen atoms by deuterium. The hydrogen atom abstraction barriers found for Cpdll are well higher in energy than those found for Cpdl. For instance, the lowest lying cyclohexane hydrogen atom abstraction barrier is $\Delta \mathrm{E}^{\ddagger}+\mathrm{ZPE}+\mathrm{E}_{\mathrm{solv}}=11.0 \mathrm{kcal} \mathrm{mol}^{-1}$ for $\mathrm{Cpdl}$ but $17.6 \mathrm{kcal} \mathrm{mol}^{-1}$ for Cpdll, whereas values of 9.6 and $15.4 \mathrm{kcal} \mathrm{mol}^{-1}$, respectively, are obtained for the reactions of $\mathrm{Cpdl}$ and Cpdll with ethylbenzene. As such, the calculations reveal that Cpdl is a much better oxidant than Cpdll in hydrogen atom abstraction reactions.

Geometrically, all hydrogen atom abstraction transition states calculated for the Cpdll mechanism are late, with long $\mathrm{C}$ $\mathrm{H}$ bonds and short $\mathrm{O}-\mathrm{H}$ interactions. Previously, ${ }^{[24]}$ we showed that late transition states generally correlate with high reaction barriers in agreement with the Hammond postulate ${ }^{[25]}$ which is also what is found here. Nevertheless, the obtained barrier heights for hydrogen atom abstraction by Cpdll from cyclohexane and ethylbenzene implicate that the reaction should be able to proceed at room temperature, although much slower than that of Cpdl. 

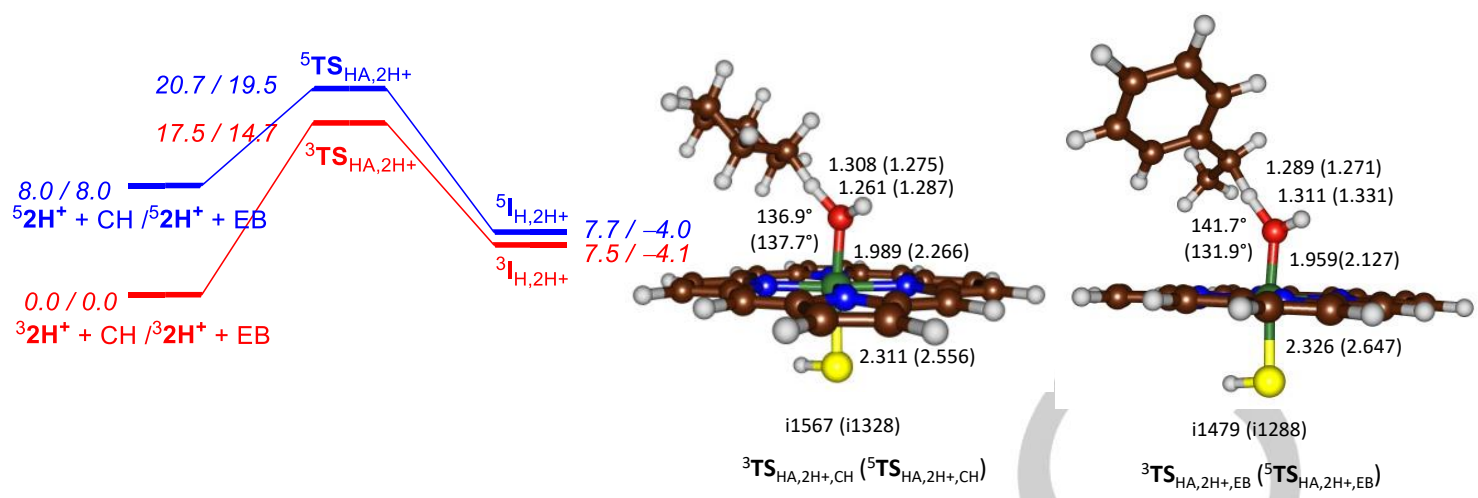

Figure 4. UB3LYP/BS2//UB3LYP/BS1 calculated potential energy landscape of cyclohexane $(\mathrm{CH})$ and ethylbenzene (EB) hydroxylation by ${ }^{3,5} \mathbf{2} \mathrm{H}^{+}$. Enthalpies (in $\mathrm{kcal} \mathrm{mol}^{-1}$ ) are calculated relative to isolated reactants and use UB3LYP/BS2 energies with zero-point and solvent corrections. Optimized geometries of the transition states give bond lengths in angstroms and the imaginary frequency in $\mathrm{cm}^{-1}$.

\section{Reactivity of protonated CpdII( $\left(2 \mathrm{H}^{+}\right)$}

The hydrogen atom abstraction barriers from cyclohexane and ethylbenzene by protonated CpdII $\left(\mathbf{2} \mathbf{H}^{+}\right)$were calculated and the obtained results are given in Figure 4. Full details are given in the Supporting Information Tables S14 - S17 and Figures S9 S12. Protonated Cpdll has well separated triplet and quintet spin states in the reactants that approach each other within a few

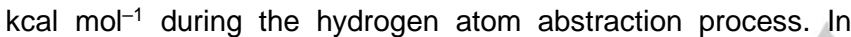
general, the barrier heights are relatively low with a $\Delta \mathrm{E}^{\ddagger}+\mathrm{ZPE}+\mathrm{E}_{\text {solv }}=17.5 \mathrm{kcal} \mathrm{mol}^{-1}$ for cyclohexane and $14.7 \mathrm{kcal}$ $\mathrm{mol}^{-1}$ for ethylbenzene on the triplet spin state. Although these barriers are very similar to those found for ${ }^{3} \mathrm{Cpdll}$, actually inclusion of thermal and entropy corrections lowers the barriers originating from protonated Cpdll well below those of Cpdll. Furthermore, both Cpdll and protonated Cpdll react with substrates via hydrogen atom abstraction with barriers that are a few kcal mol${ }^{-1}$ higher in energy than those observed for Cpdl. As such, protonated Cpdll should be able to react with substrates through hydrogen atom abstraction reactions, although not as fast as Cpdl. This is not surprising as P450 is known to dehydrogenate substrates to olefins and water.[26] During the substrate dehydrogenation, the first hydrogen atom is abstracted by $\mathrm{Cpdl}$ and the second one by an iron(IV)-hydroxo complex, i.e. protonated CpdII. ${ }^{[27]}$ These results are in line with those obtained by Abu-Omar and co-workers on manganese(V)-oxo versus manganese(IV)-hydroxo porphyrinoid cation radical systems that gave slightly better reactivity of Cpdl than protonated CpdlI models. ${ }^{[28]}$

Geometrically, the hydrogen atom abstraction transition states by protonated $\mathrm{CpdII}$ are relatively central with $\mathrm{C}-\mathrm{H}$ and $\mathrm{O}-\mathrm{H}$ distances that are very close. Similarly to what was observed for $\mathrm{Cpdl}$ and $\mathrm{Cpdll}$ the imaginary frequencies are large and should give a significant kinetic isotope effect (KIE). To confirm this we calculated KIE values for the replacement of the transferring hydrogen atom by a deuterium atom and give the details in the next section.

\section{Kinetic isotope effect of $\boldsymbol{H}$-atom abstraction}

Finally, we calculated the primary kinetic isotope effect (KIE) for the replacement of the transferring hydrogen atom of the substrate by a deuterium atom. The obtained Eyring and Wigner KIE values for the reaction of $\mathbf{1 , 2}$ and $\mathbf{2 H}^{+}$with cyclohexane and ethylbenzene are given in Table 1 . As can be seen from Table 1, structures $\mathbf{1}, \mathbf{2}$ and $\mathbf{2 H}^{+}$give similar kinetic isotope effects for hydrogen versus deuterium substituted substrate. Therefore, the calculations predict that a kinetic isotope effect experiment will not be able to distinguish the three oxidants from each other. Indeed, geometrically the transition states are very similar and all are characterized by a large imaginary frequency.

Table 1. Kinetic isotope effects for the hydrogen atom abstraction by different oxidants.

\begin{tabular}{lcccc}
\hline & \multicolumn{2}{c}{ cyclohexane } & \multicolumn{2}{c}{ ethylbenzene } \\
\hline oxidant & $\mathrm{KIE}_{\text {Eyring }}$ & $\mathrm{KIE}$ Wigner & $\mathrm{KIE}_{\text {Eyring }}$ & $\mathrm{KIE}$ Wigner \\
\hline${ }^{2} \mathbf{1}$ & 6.6 & 7.5 & 6.2 & 8.2 \\
${ }^{4} \mathbf{1}$ & 7.3 & 10.7 & 7.2 & 10.3 \\
${ }^{3} \mathbf{2}$ & 8.0 & 11.2 & 7.0 & 10.2 \\
${ }^{5} \mathbf{2}$ & 8.5 & 12.4 & 6.9 & 10.2 \\
${ }^{3} \mathbf{2 H}^{+}$ & 6.6 & 9.5 & 6.2 & 8.7 \\
${ }^{5} \mathbf{2 H}^{+}$ & 6.8 & 9.2 & 6.1 & 7.2 \\
\hline
\end{tabular}




\section{Discussion}

As shown in this paper, Cpdl, Cpdll and protonated Cpdll all react with aliphatic substrates by hydrogen atom abstraction efficiently. To understand the reactivity differences, we did a detailed orbital, thermochemical and valence bond analysis on the reactivity patterns and explain the reasons for the changes in substrate activation.

For direct comparison, we show the DFT calculated enthalpy of activation $\left(\Delta \mathrm{E}^{\ddagger}+\mathrm{ZPE}+\mathrm{E}_{\text {solv }}\right)$ of all reactions summarized together in Table 2. In general, Cpdl is the best oxidant and reacts with the lowest hydrogen atom abstraction barriers. The barriers obtained by (protonated) Cpdll are at least $5 \mathrm{kcal} \mathrm{mol}^{-1}$ higher in energy than those obtained with Cpdl. However, the barriers for the substrates tested are low enough to enable protonated Cpdll, Cpdll and Cpdl to react via hydrogen atom abstraction at room temperature. Interestingly, the obtained barriers for Cpdll and protonated Cpdll are almost the same. In line with previous reactivity studies using different oxidants and the same substrate the trends are equal. ${ }^{[29]}$

Table 2. DFT calculated enthalpy of activation for hydrogen atom abstraction by different oxidants..$^{[a, b]}$

\begin{tabular}{lcc}
\hline cyclohexane & ethylbenzene \\
oxidant & $\Delta \mathrm{E}^{\ddagger}+\mathrm{ZPE}+\mathrm{E}_{\text {solv }}$ & $\Delta \mathrm{E}^{\ddagger}+\mathrm{ZPE}+\mathrm{E}_{\text {solv }}$ \\
\hline${ }^{2} \mathbf{1}$ & 11.0 & 9.6 \\
${ }^{4} \mathbf{1}$ & 13.7 & 10.4 \\
${ }^{3} \mathbf{2}$ & 17.6 & 15.4 \\
${ }^{5} \mathbf{2}$ & 30.1 & 25.6 \\
${ }^{3} \mathbf{2 H}^{+}$ & 17.5 & 14.7 \\
${ }^{5} \mathbf{2 H}^{+}$ & 20.7 & 19.5 \\
\hline
\end{tabular}

[a] Values in kcal $\mathrm{mol}^{-1}$. [b] Energies obtained at UB3LYP/BS2//UB3LYP/BS1 and include zero-point and solvent corrections

The problem associated with the reaction starting with protonated Cpdll is that it can only abstract one hydrogen atom and is not possible to rebound a hydroxo group to form alcohol product complexes, since a product water molecule is formed after hydrogen atom abstraction. Consequently, protonated Cpdll only will be able to catalyze one-electron transfer reactions rather than a 2-electron transfer process as is necessary in substrate hydroxylation or epoxidation reactions. For instance, protonated Cpdll should be able to react with substrates like TEMPOH (2,2,6,6-tetramethyl-piperidine-1-ol).

To understand the observed trends and to rationalize the results and make predictions, we analyzed the results in detail and designed valence bond models that describe the various reaction pathways. We will start with giving a description of differences in the reactants and their thermochemical properties.

\section{Electronic differences of oxidants}

To gain insight into the reactivity differences between 1, 2 and $2 \mathrm{H}^{+}$, let us first analyze the electronic differences of the reactants. Scheme 1 shows the high-lying occupied and virtual orbitals of each of the oxidants. Firstly, there is a high lying heme orbital that in $D_{4 h}$ symmetry has the label $a_{2 u}{ }^{[18,30]}$ It is singly occupied in Cpdl and doubly occupied in Cpdll and protonated Cpdll. The metal-type orbitals are split into two pair of $\sigma$-orbitals: the $\sigma_{x y} / \sigma^{*} x y$ pair for the interactions of the metal with the heme nitrogen atoms and the $\sigma_{z 2} / \sigma_{z 2}^{*}$ pair for the interactions with the axial and distal ligands. These bonding orbitals are doubly occupied and the antibonding ones virtual in all ground state structures. In addition, there is a nonbonding $\delta_{x 2-y 2}$ orbital that is also doubly occupied in all ground state structures. To complement the set of metal-type orbitals, there are $\pi$-orbitals located along the $\mathrm{Fe}-\mathrm{O}$ bond. In $\mathrm{Cpdl}$ and Cpdll, two sets of $\pi$ orbitals exist, namely $\pi_{\mathrm{xz}} / \pi_{\mathrm{xz}}^{*}$ and $\pi_{\mathrm{yz}} / \pi^{*} \mathrm{yz}$, whereby the bonding orbitals are doubly occupied and the anti-bonding orbitals singly occupied.

Overall, the orbital occupation of Cpdl is [core] $\pi_{x z}{ }^{2} \delta_{x 2-y 2}{ }^{2}$ $\pi^{*}{ }_{x z}^{1} \pi^{*}{ }_{y z}{ }^{1} a_{2 u}{ }^{1}$ with [core] $\sigma_{x y}{ }^{2} \sigma_{z z}{ }^{2} \pi_{y z}{ }^{2}$, whereby the spin of the unpaired electron in the $a_{2 u}$ orbital can be either up or down. This will give the two isoelectronic states of Cpdl, designated ${ }^{4,2} \mathrm{~A}_{2 u}$ with the same orbital occupation. The one-electron reduced form of Cpdl, i.e. Cpdll, has an extra electron in $\mathrm{a}_{24}$ to make it doubly occupied and, therefore, Cpdll has a single ground state with two unpaired electrons ferromagnetically coupled in the two $\pi^{\star}$ orbitals with electronic state designated ${ }^{3} \Pi$. Consequently, both Cpdl and Cpdll have the metal in oxidation state iron(IV) and are only distinguished by an extra electron in the $\mathrm{a}_{2 u}$ orbital in the case of Cpdll. Geometrically, therefore, $\mathrm{Cpdl}$ and Cpdll are very similar with analogous $\mathrm{Fe}-\mathrm{O}$ and $\mathrm{Fe}-\mathrm{S}$ distances as seen from the optimized geometries. Technically, there also is a possibility of an iron(III)-oxo porphyrin cation radical state for Cpdll (and protonated CpdII) with electronic configuration [core] $\pi_{\mathrm{xz}}{ }^{2} \delta_{\mathrm{x} 2-\mathrm{y} \mathrm{y}^{2}} \pi^{*}{ }_{\mathrm{xz}}{ }^{2} \pi^{*}{ }_{\mathrm{yz}}{ }^{1} \mathrm{a}_{\mathrm{zu}}{ }^{1}$. However, previous work showed this state to be higher in energy by about $5 \mathrm{kcal}$ $\mathrm{mol}^{-1}$.[31]

In protonated Cpdll $\left(\mathbf{2 H}^{+}\right)$, the situation is slightly different as due to the formation of the $\mathrm{O}-\mathrm{H}$ bond, the $\pi_{\mathrm{xz}} / \pi^{*} \mathrm{xz}$ pair of orbitals has split back into atomic orbitals and the system has an atomic $3 d_{x z}$ orbital on iron and a $\sigma_{\mathrm{OH}}$ bond with two electrons. Protonated Cpdll, therefore, has an electronic configuration [core] $\delta_{\mathrm{x} 2-\mathrm{y} 2^{2}} 3 \mathrm{~d}_{\mathrm{xz}}{ }^{1} \pi_{\mathrm{yz}}^{*} \mathrm{a}_{2 \mathrm{u}^{2}} \sigma_{\mathrm{OH}}{ }^{2}$ with an electronic ground state designated ${ }^{3} \Pi$. Because, the valence $\pi^{*}{ }_{x z}$ orbital has changed into a nonbonding orbital between CpdII and protonated CpdII this will result in considerably different orbital energy levels with respect to Cpdl and Cpdll and will affect its electron and proton affinities. The orbital changes between Cpdll and protonated Cpdll will mean that the $\mathrm{Fe}-\mathrm{O}$ bond has more bonding character in Cpdl and Cpdll than in protonated CpdlI. In particular, the Fe$O$ bond in Cpdl and Cpdll should be seen as two two-center three-electron $(2 \mathrm{c}-3 \mathrm{e})$ bonds: one in the $\mathrm{xz}$-plane and one in the yz-plane. 


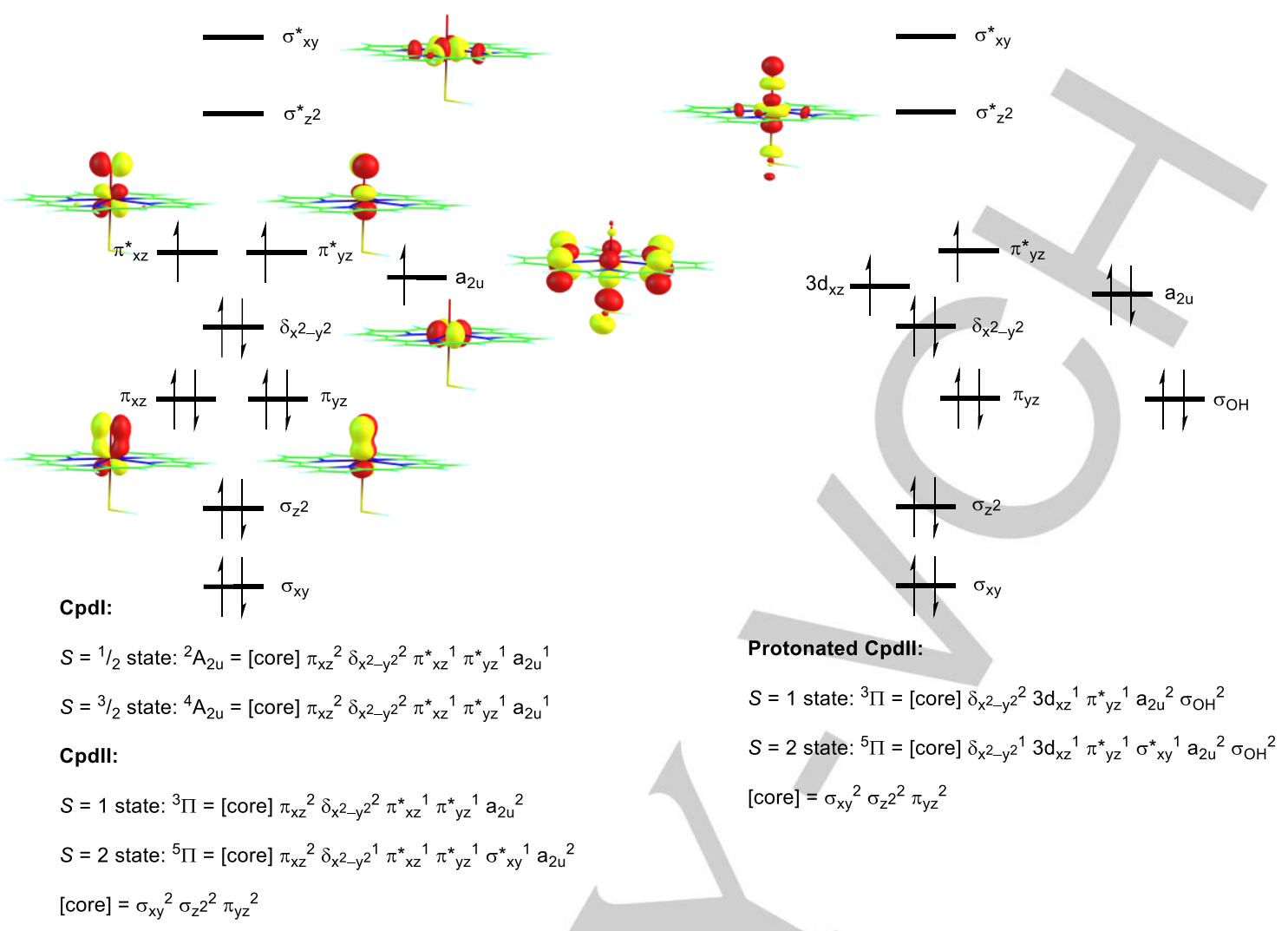

Scheme 1. Orbital diagram and occupations of the low-lying states investigated for Cpdl, Cpdll and protonated Cpdll.

By contrast, protonated Cpdll only has one 2c-3e bond along the $\mathrm{Fe}-\mathrm{O}$ bond in the $\mathrm{yz}$-plane and the bond-character is reduced. As a consequence, the $\mathrm{Fe}-\mathrm{O}$ distance is elongated in the protonated Cpdll reactant as compared to Cpdl and Cpdll. Indeed, $\mathrm{Fe}-\mathrm{O}$ distances of 1.649 and $1.678 \AA$ for ${ }^{2} 1$ and ${ }^{3} 2$ are found with DFT methods, while ${ }^{3} \mathbf{2} \mathbf{H}^{+}$has an $\mathrm{Fe}-\mathrm{O}$ bond length of $1.826 \AA$ in agreement with the orbital assignment of Scheme 1. In the following, we will discuss how the molecular orbitals change during the hydrogen atom abstraction mechanism and what chemical properties of oxidant and substrate drive the reaction and determine the rate constant.

\section{Thermochemical modelling}

To understand the reactivity differences and the relative driving forces for the potential energy landscapes obtained above, we did a detailed thermochemical analysis of the reaction pathways and the ability of all oxidants to abstract electrons, protons and hydrogen atoms. Figure 5 gives the thermochemical cycle for hydrogen atom abstraction from substrate (SubH) by Cpdl (top) and Cpdll (bottom). Thus, Cpdl is converted into an iron(IV)hydroxo species, i.e. protonated Cpdll $\left(\mathbf{2 H}^{+}\right)$, while Cpdll leads to an iron(III)-hydroxo complex. To close the Born cycle we consider the vertical reactions in Figure 5 as the reduction of Cpdl to Cpdll (left) and the reduction of protonated Cpdll (right).
Energetically, therefore, the sum of the four reactions in Figure 5 should be equal to zero, Eq 1, whereby the hydrogen atom abstraction driving forces are given as $\Delta \mathrm{H}_{\mathrm{HAT}}$ and the electron affinity of $\mathbf{1}$ and $2 \mathrm{H}^{+}$as $E A_{1}$ and $\mathrm{EA}_{2 \mathrm{H}+}$.

$\Delta \mathrm{H}_{\mathrm{HAT}, 1}-\mathrm{EA}_{2 \mathrm{H}+}-\Delta \mathrm{H}_{\mathrm{HAT}, 2}+\mathrm{EA}_{1}=0$

Or, in other words, the difference in hydrogen atom abstraction ability between Cpdl and Cpdll is equal to the difference in electron affinity between Cpdl and protonated CpdlI, Eq 2.

$\Delta \mathrm{H}_{\mathrm{HAT}, 1}-\Delta \mathrm{H}_{\mathrm{HAT}, 2}=\mathrm{EA}_{2 \mathrm{H}_{+}}-\mathrm{EA}_{1}$

If we assume that the rate constant for hydrogen atom abstraction is proportional to the driving force we can rewrite Eq 2 as a natural logarithm of the rate constant ratio ( $\mathrm{k}_{\text {HAT }}$ ) between Cpdl and Cpdll with $R$ being the gas constant and $T$ the temperature the reaction takes place at (Eq 3$)$. This equation predicts that the hydrogen atom abstraction rates between $\mathrm{Cpdl}$ and CpdII are dependent on the difference in electron affinity of Cpdl and protonated Cpdll. We calculated the values of these electron affinities and find $a \Delta E+Z P E+E_{\text {solv }}=108.1$ and 104.5 kcal mol${ }^{-1}$ for the $\mathrm{EA}_{1}$ and $\mathrm{EA}_{2 \mathrm{H}_{+}}$, respectively. 

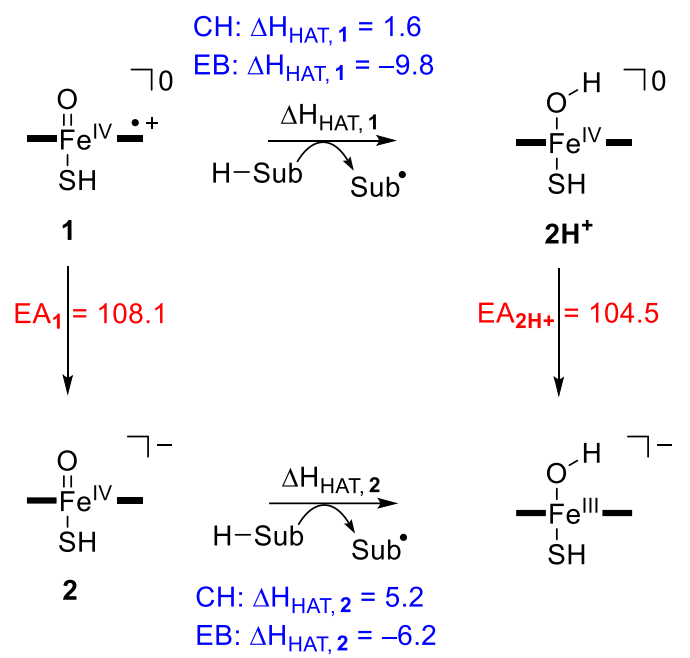

$\mathrm{CH}: \Delta \mathrm{H}_{\mathrm{HAT}, 2 \mathrm{H}+}=7.5$

EB: $\Delta \mathrm{H}_{\mathrm{HAT}, 2 \mathrm{H}+}=-3.9$

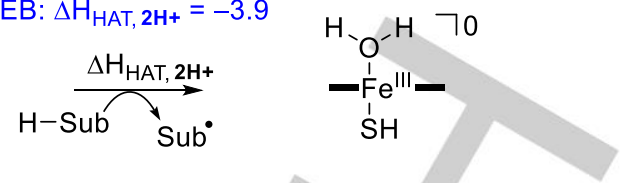

theory in $\mathrm{kcal} \mathrm{mol}^{-1}$ from isolated species.

A driving force difference of $3.6 \mathrm{kcal} \mathrm{mol}^{-1}$ between the hydrogen atom abstraction by $\mathrm{Cpdl}$ and Cpdll would refer to a barrier height difference of about $1 / 3$ of this, ${ }^{[32]}$ and consequently, the thermochemical analysis predicts Cpdl to react with barriers that will be lower than those with Cpdll using the same substrate of about $1.2 \mathrm{kcal} \mathrm{mol}^{-1}$

$-R T \ln \left(\mathrm{k}_{\mathrm{HAT}, 1} / \mathrm{k}_{\mathrm{HAT}, 2}\right)=\mathrm{EA}_{2 \mathrm{H}+}-\mathrm{EA}_{1}$

This value is in reasonable agreement with the barrier height differences shown in Table 2 for the various substrates tested. A free energy change of $1.2 \mathrm{kcal} \mathrm{mol}^{-1}$ between the $\mathrm{Cpdl}$ and Cpdll hydrogen atom abstraction barriers would correspond with a rate enhancement by a factor of 10 . Therefore, the Born cycle shown in Figure 5 implicates that Cpdl will always be the better oxidant over Cpdll as its electron affinity is larger and, consequently, has better ways to absorb an extra electron into its orbital system. Thus, electron transfer into Cpdl during the hydrogen atom abstraction process will fill the $\mathrm{a}_{2 u}$ orbital with a second electron, while in Cpdll the electron fills a higher-lying $\pi^{*}{ }_{x z}$ orbital instead. The difference in reduction potential between the two oxidants makes Cpdl the better oxidant of the two.

Note, that the $\Delta \mathrm{H}_{\text {HAT }}$ energies can be written as a function of the bond dissociation energies (BDEs) of the bonds that are broken and formed in the process. ${ }^{[33]}$ BDEs are defined as given in Eq 4 for the splitting of molecule $\mathrm{AH}$ into a hydrogen atom and a radical $A^{*}$. As such, we calculated the homolytic cleavage of the $\mathrm{O}-\mathrm{H}$ bond of the iron-hydroxo complexes $\left(\mathrm{BDE}_{\mathrm{OH}}\right)$ but also the breaking of the $\mathrm{C}-\mathrm{H}$ bond of the aliphatic group of the substrates $\left(\mathrm{BDE}_{\mathrm{CH}}\right)$.

$\mathrm{AH} \rightarrow \mathrm{A}^{\cdot}+\mathrm{H}^{\cdot}+\mathrm{BDE}_{\mathrm{AH}}$
In principle, the hydrogen atom transfer reaction from substrate to oxidant, $\Delta \mathrm{H}_{\mathrm{HAT}, 1}$, can be described as the difference in energy of the $\mathrm{C}-\mathrm{H}$ bond that is broken and the $\mathrm{O}-\mathrm{H}$ bond formed in the process, Eq. 5.

$$
\Delta \mathrm{H}_{\mathrm{HAT}, 1}=\mathrm{BDE}_{\mathrm{CH}}-\mathrm{BDE}_{\mathrm{OH}, 1}
$$

When we combine Eq 5 with $\mathrm{Eq} 2$ it gives $\mathrm{Eq} \mathrm{6,} \mathrm{where} \mathrm{the}$ $\mathrm{BDE}_{\mathrm{OH}}$ values of $\mathbf{1}$ and $\mathbf{2}$ are connected to the electron affinities of $\mathbf{1}$ and $\mathbf{2} \mathbf{H}^{+}$.

$\mathrm{BDE}_{\mathrm{OH}, 2}-\mathrm{BDE}_{\mathrm{OH}, 1}=\mathrm{EA}_{2 \mathrm{H}_{+}}-\mathrm{EA}_{1}$

Therefore, the Born-cycle displayed in Figure 5 implies that the change in $\mathrm{BDE}_{\mathrm{OH}}$ from 1 to 2 will be equal to the difference in electron affinity between $\mathbf{1}$ and $2 \mathrm{H}^{+}$. We calculated $\mathrm{BDE}_{\mathrm{OH}}$ values (at the $\triangle E+Z P E+E_{\text {solv }}$ level of theory) of 88.1 and 91.7 $\mathrm{kcal} \mathrm{mol}^{-1}$ for 2 and 1, respectively, whereas EA values of 108.1 and $104.5 \mathrm{kcal} \mathrm{mol}^{-1}$ are found for $\mathbf{1}$ and $\mathbf{2} \mathbf{H}^{+}$(see Table S5 of the Supporting Information). In agreement with Eq 6, therefore, both $\mathrm{BDE}_{\mathrm{OH}}$ and EA differences are $-3.6 \mathrm{kcal} \mathrm{mol}^{-1}$. This is an interesting result as the $\mathrm{BDE}_{\mathrm{OH}}$, technically, can be dissected into a separate electron and proton transfer through Eq 7. ${ }^{[3]}$ Consequently, the $\mathrm{BDE}_{\mathrm{OH}}$ is described with contributions for electron transfer (EA), proton transfer (via the gas-phase acidity, $\Delta G_{\text {acid }}$ ) and the ionization energy of a hydrogen atom, $I_{H}$. Substitution of Eq 7 into Eq 6 gives Eq 8.

$\mathrm{BDE}_{\mathrm{OH}}=\Delta \mathrm{G}_{\mathrm{acid}}+\mathrm{EA}-\mathrm{IE}_{\mathrm{H}}$

$\mathrm{EA}_{2 \mathrm{H}+}-\mathrm{EA}_{1}=\Delta \mathrm{G}_{\mathrm{acid}, 2}-\Delta \mathrm{G}_{\mathrm{acid}, 1}$ 
(a)

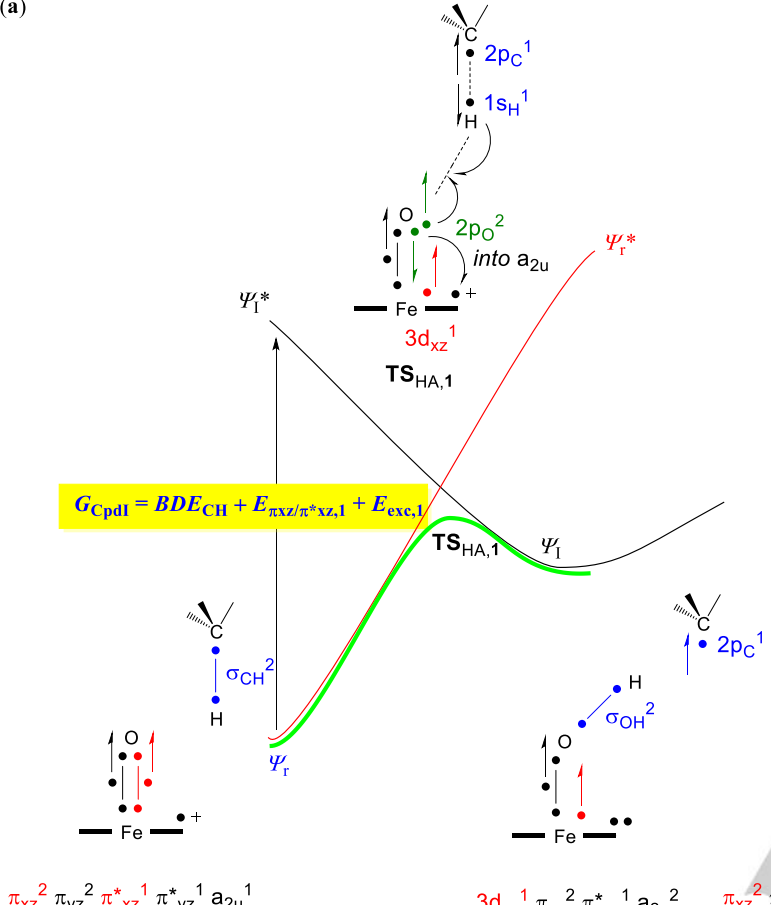

(b)

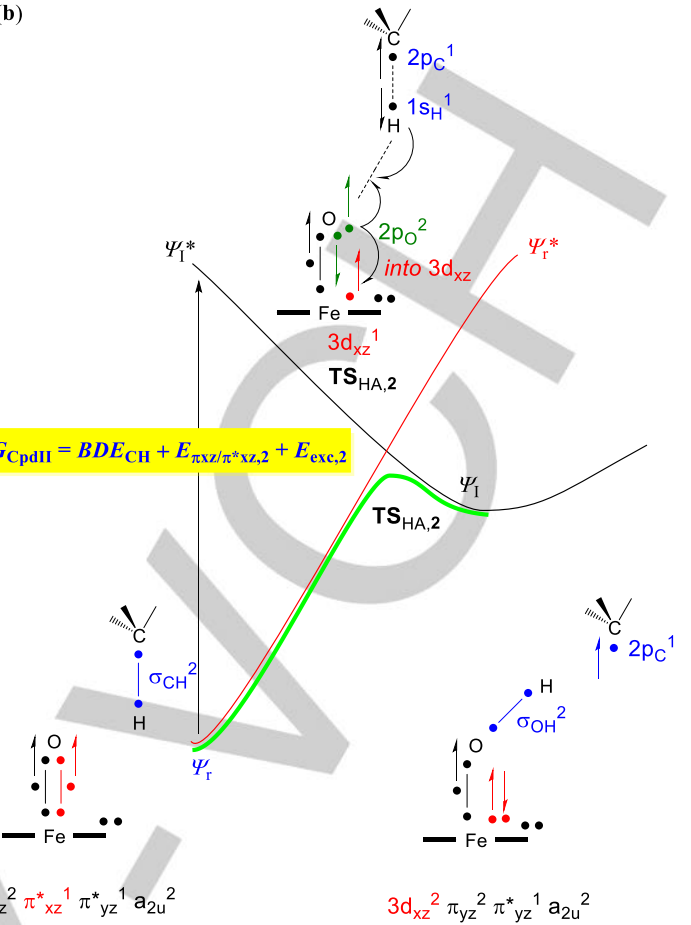

Figure 6. VB curve crossing diagram for hydrogen atom abstraction of a substrate by (a) Cpdl and (b) Cpdll. Dots represent valence electrons and a line represents a bond between two atoms.

As such, Eq 8 shows that the difference in electron affinity of Cpdl and protonated Cpdll is directly related to the relative acidity differences between Cpdl and Cpdll. As the electron affinity of protonated Cpdll is $54.4 \mathrm{kcal} \mathrm{mol}^{-1}$ larger than that of Cpdll, based on Eq 8 an acidity difference between Cpdl and Cpdll by the same amount is expected. This acidity difference was indeed confirmed from our DFT calculations of the various complexes involved. Moreover, the difference in $\mathrm{BDE}_{\mathrm{OH}}$ between Cpdll and protonated Cpdll reveals that protonated Cpdll should be a slightly better oxidant than Cpdll.

For all oxidants and substrates we calculated $\mathrm{BDE}_{\mathrm{OH}}$ and $\mathrm{BDE}_{\mathrm{CH}}$ values separately. We find a $\mathrm{BDE}_{\mathrm{OH}}$ of $91.7,88.1$ and $85.8 \mathrm{kcal} \mathrm{mol}^{-1}$ for $\mathbf{1 , 2}$ and $2 \mathrm{H}^{+}$at the $\Delta \mathrm{E}+\mathrm{ZPE}+\mathrm{E}_{\text {solv }}$ level of theory, while $\mathrm{BDE}_{\mathrm{CH}}$ values of 93.3 and $81.9 \mathrm{kcal} \mathrm{mol}^{-1}$ are found for cyclohexane and ethylbenzene. As such, following on from Eq 5, from isolated oxidants and substrates, we would predict a driving force for hydrogen atom abstraction from cyclohexane based on isolated molecules (Figure 5) of $+1.6,5.2$ and $7.5 \mathrm{kcal} \mathrm{mol}^{-1}$ for $\mathbf{1}, \mathbf{2}$ and $\mathbf{2} \mathbf{H}^{+}$, respectively. These values are within a few kcal mol-1 of those given in Figures 2, 3 and 4 and similar values are found for the ethylbenzene reactions. Therefore, the driving forces give the accepted reactivity trends with an almost thermoneutral cyclohexane hydrogen atom abstraction by $\mathbf{1}$, while it is endothermic for both 2 and $2 \mathrm{H}^{+}$. Furthermore, if these driving forces link directly to rate constants the thermochemical cycle from Figure 5 predicts higher reactivity of Cpdl with respect to Cpdll and protonated CpdlI.

\section{Valence bond and molecular orbital models}

In the past we used valence bond (VB) diagrams successfully to rationalise regioselectivities of bifurcation processes and, in particular, looked at aliphatic and aromatic hydroxylation processes. ${ }^{[22 b, 32,34]}$ Figure 6 shows the VB curve crossing diagrams for Cpdl and Cpdll reacting with an aliphatic group. The diagram starts on the left-hand-side with a VB description of the relevant orbitals involved in the reaction processes. In the reactants there are two electrons that occupy the substrate $\sigma_{\mathrm{CH}}$ orbital representing the $\mathrm{C}-\mathrm{H}$ bond. On the oxidant side, in $\mathrm{Cpdl}$ there are six electrons occupying the $\pi$ and $\pi^{*}$ orbitals along the $\mathrm{Fe}-\mathrm{O}$ bond, which give an electronic configuration $\pi_{\mathrm{xz}}{ }^{2} \pi_{\mathrm{yz}}{ }^{2} \pi^{*}{ }_{\mathrm{xz}}{ }^{1}$ $\pi^{*}{ }^{*}{ }^{1}$. Finally, the oxidant has an unpaired electron in a ligandtype orbital, namely $\mathrm{a}_{2 u}$. As such, the reactant state with wave function $\Psi_{\mathrm{r}}$ will have a VB orbital occupation of $\pi_{\mathrm{xz}}{ }^{2} \pi_{\mathrm{yz}}{ }^{2} \pi^{*}{ }_{\mathrm{xz}}{ }^{1}$ $\pi^{*}{ }_{\mathrm{yz}}{ }^{1} \mathrm{a}_{2 \mathrm{u}}{ }^{1} \sigma_{\mathrm{CH}}{ }^{2}$.

Subsequently, we consider the mechanism for hydrogen atom abstraction and the formation of an iron(IV)-hydroxo complex. Thus, the iron(IV)-hydroxo complex has a doubly occupied $\mathrm{O}-\mathrm{H}$ orbital $\left(\sigma_{\mathrm{OH}}\right)$, as well as a doubly occupied $\mathrm{a}_{2 \mathrm{u}}$ orbital. Finally, the metal has orbital occupation $\pi_{y z}^{2} \pi^{*}{ }^{1}{ }^{1} 3 d_{x z}{ }^{1}$. As such the hydrogen abstraction intermediate will have a wave function $\Psi_{1}$ and orbital occupation of $\pi_{\mathrm{yz}}{ }^{2} \pi^{*}{ }_{\mathrm{yz}}{ }^{1} 3 \mathrm{~d}_{\mathrm{xz}}{ }^{1} \mathrm{a}_{2 \mathrm{u}}{ }^{2} \sigma_{\mathrm{OH}}{ }^{2}$ $2 \mathrm{p}_{\mathrm{c}}{ }^{1}$, whereby the latter orbital represents the radical on the substrate.

In VB theory, the reactant wave function is connected to an excited state in the radical intermediate geometry, whereas the radical intermediate configuration connects to an excited state in the reactant geometry. The excitation energy in the reactant geometry to change from the reactant to the radical intermediate configuration is generally proportional to the barrier height of the reaction process. ${ }^{[32]}$ As such the electronic and thermochemical properties associated with the change from reactant to radical 
intermediate state determine the hydrogen atom abstraction barrier.

This state is given above the transition state barrier and highlights the orbital changes and electron migration pathways. In the case of $\mathrm{Cpdl}$, the aliphatic $\mathrm{C}-\mathrm{H}$ bond breaks into atomic orbital contributions (shown in blue) and splits into $2 \mathrm{p}_{\mathrm{C}}$ and $1 \mathrm{~s}_{\mathrm{H}}$ each with one electron. In addition, the $\pi_{x z} / \pi^{*} x z$ pair of orbitals splits back to atomic orbitals, namely $3 d_{x z}$ and $2 p_{0}$, whereby the latter takes two electrons and the former one electron. One of the electrons in $2 p_{0}$ pairs up with the incoming hydrogen atom in $1 \mathrm{~s}_{\mathrm{H}}$ to form the new $\sigma_{\mathrm{OH}}$ bond with two electrons. The second electron in the $2 \mathrm{p}_{\mathrm{o}}$ orbital is promoted to the lowest available orbital and in the case of Cpdl fills the $\mathrm{a}_{2 \mathrm{u}}$ orbital with a second electron.

The promotion gap $\mathrm{G}_{\mathrm{cpdl}}$ for the excitation from the ground state wave function $\Psi_{\mathrm{r}}$ to the radical intermediate wave function $\Psi_{1}{ }^{*}$ will be proportional to the energy to break the $\mathrm{C}-\mathrm{H}$ orbital of the substrate $\left(\mathrm{BDE}_{\mathrm{CH}}\right)$, the energy to break one of the $\pi$-bonds along the $\mathrm{Fe}-\mathrm{O}$ bond $\left(\mathrm{E}_{\pi \times z / \pi^{*} \times z}\right)$ as well as some excitation energy of an electron from $2 p_{o}$ to $a_{2 u}\left(E_{e x c, 1}\right),{ }^{[35]} E q 9$.

$\mathrm{G}_{\mathrm{cpdl}}=\mathrm{BDE}_{\mathrm{CH}}+\mathrm{E}_{\pi \mathrm{xz} / \pi^{*} \times z}+\mathrm{E}_{\mathrm{exc}, 1}$

The promotion gap can be used to predict barrier heights from empirical values. Recently, we devised a novel two-parabola curve crossing diagram and related the promotion gap to the transition state energy $\left(\Delta \mathrm{E}_{\mathrm{VB}^{\ddagger}}\right)^{\left[{ }^{[36]}\right.} \mathrm{Eq} 10$, with $\Delta \mathrm{E}_{\mathrm{rp}}$ the driving force for the reaction and $B$ the resonance energy. For the promotion gap we took the $\mathrm{BDE}_{\mathrm{CH}}$ value of the substrate, the energy to break the $\pi_{x z} / \pi^{*}$ pair of or-bitals $\left(E_{\pi x z / \pi^{*} x z, 1}=83.0 \mathrm{kcal}\right.$ $\left.\mathrm{mol}^{-1}\right)$ and the excitation energy from $\pi_{\mathrm{xz}}$ to $\mathrm{a}_{2 \mathrm{u}}\left(\mathrm{E}_{\mathrm{exc}, 1}=53.0 \mathrm{kcal}\right.$ $\mathrm{mol}^{-1}$ ). In addition, for the resonance energy we use the weakest bond that is either broken or formed. ${ }^{[32]}$ Based on these values, the VB model predicts hydrogen atom abstraction barriers of 16.2 and $8.3 \mathrm{kcal} \mathrm{mol}^{-1}$ for cyclohexane and ethylbenzene, respectively.

$\Delta \mathrm{E}_{\mathrm{VB}}{ }^{\ddagger}=1 / 4 \mathrm{G}_{\mathrm{Cpdl}}+{ }^{3} / 4 \Delta \mathrm{E}_{\mathrm{rp}}-\mathrm{B}$

On the right-hand-side of Figure 6 we show the VB diagram for the reaction of Cpdll with an aliphatic $\mathrm{C}-\mathrm{H}$ bond. Of course, the profile and VB descriptions show many similarities and the only difference on the reactant side is the doubly occupied $a_{2 u}$ orbital. During the hydrogen atom abstraction process, the $\mathrm{C}-\mathrm{H}$ bond of the substrate is broken into atomic orbitals, which will incur the same amount of energy as that seen for the reaction of Cpdl with substrate. Also the $\pi_{\mathrm{xz}} / \pi^{*} \mathrm{xz}$ pair of orbitals is split back into atomic orbitals; however, no electron transfer into the $\mathrm{a}_{2 \mathrm{u}}$ orbital is possible. Therefore, in Cpdll the lowest available molecular orbital is the higher lying $3 d_{x z}$ orbital that becomes doubly occupied. The promotion gap for hydrogen atom abstraction by CpdII ( $\mathrm{G}_{\text {cpdII }}$ ) can now be described by Eq 11 and split into an energy to break the $\mathrm{C}-\mathrm{H}$ bond, the energy to break the $\pi_{\mathrm{xz}} / \pi_{\mathrm{xz}}^{*}$ orbitals along the $\mathrm{Fe}-\mathrm{O}$ bond and some orbital excitation energy, $E_{\text {exc,2. }}$. The alternative situation where an upspin fills the $\sigma_{z 2}^{*}$ orbital to give the triplet spin state with configuration $\pi_{\mathrm{yz}}{ }^{2} \pi_{\mathrm{yz}}^{*} 3 \mathrm{~d}_{\mathrm{xz}}{ }^{\uparrow} \sigma_{\mathrm{z} 2}^{*} \mathrm{a}_{2 \mathrm{u}^{2}} 2 \mathrm{p}_{\mathrm{c}}{ }^{\downarrow}$ is higher in energy.

$\mathrm{G}_{\mathrm{Cpdll}}=\mathrm{BDE}_{\mathrm{CH}}+\mathrm{E}_{\pi \times \mathrm{z} / \pi^{*} \times z, 2}+\mathrm{E}_{\mathrm{exc}, 2}$
The VB diagram of Cpdl versus Cpdll reactivity in hydrogen atom abstraction reactions predict that they depend on the nature of the oxidant as in both cases $\mathrm{BDE}_{\mathrm{CH}}$ will be the same. Furthermore, in both cases the $\pi_{\mathrm{xz}} / \pi^{*} \mathrm{xz}$ set of orbitals is split into atomic orbitals and the same $\mathrm{O}-\mathrm{H}$ bond is formed through pairing of a $2 \mathrm{p}_{\mathrm{O}}$ electron with a $1 \mathrm{~s}_{\mathrm{H}}$ electron. It is, therefore, not expected that the diabatic $\mathrm{O}-\mathrm{H}$ bond energy will be dramatically different between Cpdl and Cpdll. The adiabatic $\mathrm{O}-\mathrm{H}$ bond formation energy of Cpdl and Cpdll, however, includes the orbital reorganization and therefore should give considerable difference as it involves an electron transfer into the $a_{2 u}$ orbital for Cpdl, whereas a higher energy orbital is filled in the case of Cpdll. To quantify values for the barrier heights based on VB theory, we analyzed the orbital energies of the reactant structures and find $E_{\pi \times z / \pi^{*} \times z, 2}=77.9 \mathrm{kcal} \mathrm{mol}^{-1}$ and $E_{\mathrm{exc}, 2}=68.2$

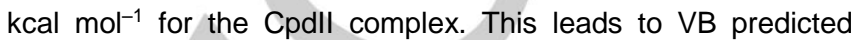
hydrogen atom abstraction barriers of 19.3 and $11.4 \mathrm{kcal} \mathrm{mol}^{-1}$ for cyclohexane and ethylbenzene, respectively. These VB predicted barriers for Cpdl and Cpdll are in good quantitative agreement with the DFT calculated barriers from Figures 2 and 3. Moreover, it is seen that the barriers of Cpdll are substantially higher in energy than those for Cpdl mainly due to enlarged excitation energy $E_{\text {exc. }}$.

In summary, the VB crossing diagram predicts Cpdll to be a weaker oxidant than Cpdl in aliphatic hydrogen atom abstraction reactions because of the fact that the electron transfer from oxygen to iron-porphyrin fills a higher lying orbital. This is in agreement with the relative barrier heights of the various hydrogen atom abstraction processes, where we find significantly lower barriers for Cpdl than Cpdll with the same substrate.

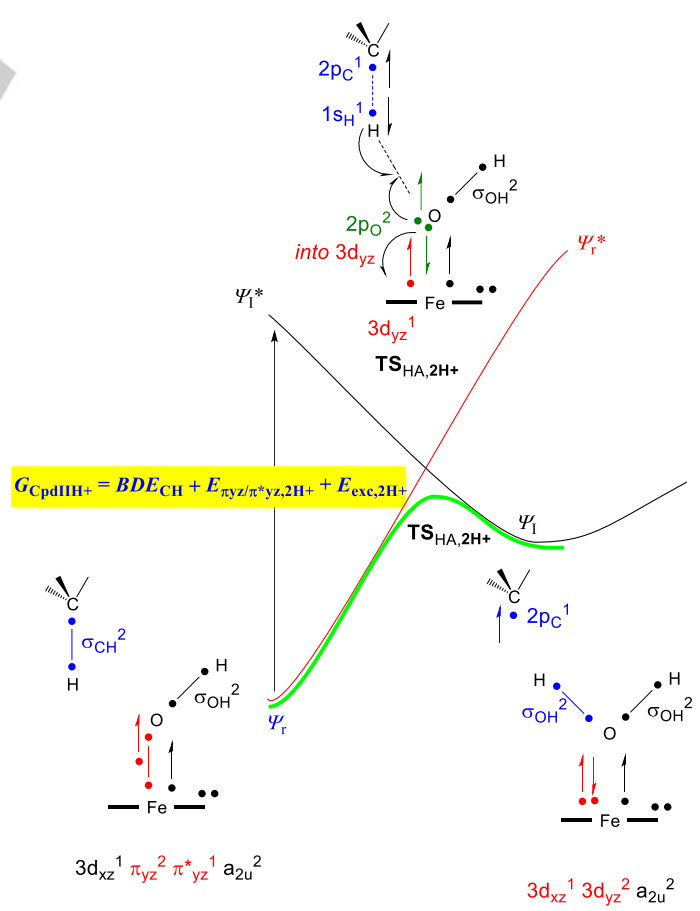

Figure 7. VB curve crossing diagram for hydrogen atom abstraction of a substrate by protonated CpdII. Dots represent valence electrons and a line represents a bond between two atoms. 
Subsequently, we set up a VB curve crossing diagram for protonated Cpdll, see Figure 7. Thus, protonated Cpdll has a reactant orbital configuration of $3 \mathrm{~d}_{\mathrm{xz}}{ }^{1} \pi_{\mathrm{yz}}{ }^{2} \pi_{\mathrm{yz}}^{*} \mathrm{a}_{2 \mathrm{u}}{ }^{2} \sigma_{\mathrm{OH}}{ }^{2}$ and the substrate has two electrons in the $\mathrm{C}-\mathrm{H}$ bond $\left(\sigma_{\mathrm{CH}}{ }^{2}\right)$. As above, the $\mathrm{C}-\mathrm{H}$ bond breaks and a new bond between the departing hydrogen atom with the accepting oxygen atom forms to give a water molecule. At the same time the $\pi_{y z} / \pi^{*} y z$ pair of orbitals splits back to atomic orbitals, whereby one electron on oxygen forms a new bond with the hydrogen atom ( $\sigma_{\mathrm{OH}}$ in blue) and the other two electrons fill the $3 d_{y z}$ orbital.

The promotion gap for the reaction of protonated Cpdll with an aliphatic $\mathrm{C}-\mathrm{H}$ bond will be $\mathrm{G}_{\mathrm{CpdllH}+}$ and is described in $\mathrm{Eq} 12$. Similarly as Cpdl and Cpdll, the promotion gap is dependent on the energy to break the $\mathrm{C}-\mathrm{H}$ bond of the substrate. In addition, it is contains contributions for the energy to break the $\pi_{y z} / \pi^{*}$ yz pair of orbitals along the $\mathrm{Fe}-\mathrm{OH}$ bond $\left(\mathrm{E}_{\pi \mathrm{yz} / \pi^{*} \mathrm{yz}, 2 \mathrm{H}+}\right)$ and excitation energy to transfer an electron from $2 \mathrm{p}_{\mathrm{o}}$ into $3 d_{\mathrm{yz}}\left(\mathrm{E}_{\mathrm{exc}, 2 \mathrm{H}+}\right)$.

$\mathrm{G}_{\mathrm{CpdllH+}}=\mathrm{BDE}_{\mathrm{CH}}+\mathrm{E}_{\pi y \mathrm{z} / \pi^{*} \mathrm{yz}, 2 \mathrm{H}+}+\mathrm{E}_{\mathrm{exc}, 2 \mathrm{H}+}$

From the molecular orbitals energies of the iron(IV)-hydroxo complex, we estimate the energy to break the $\pi_{y z} / \pi^{*} y z$ pair of orbitals as $\mathrm{E}_{\pi y z / \pi^{*} \mathrm{yz}, 2 \mathrm{H}+}=100.6 \mathrm{kcal}^{\mathrm{mol}}{ }^{-1}$, while an excitation energy of $48.0 \mathrm{kcal} \mathrm{mol}^{-1}$ will be needed. These values lead to predicted hydrogen atom abstraction barriers by $2 \mathrm{H}^{+}$of 21.7 and $13.8 \mathrm{kcal} \mathrm{mol}^{-1}$ for cyclohexane and ethylbenzene, respectively. The calculations predict a slightly better hydrogen atom abstraction ability by Cpdll as compared to protonated Cpdll, although the difference may not be significant. Using DFT model complexes the barrier heights for hydrogen atom abstraction from cyclohexane and ethylbenzene by Cpdll and protonated Cpdll were almost the same. Nevertheless, the best oxidant of the three considered is clearly $\mathrm{Cpdl}$ by several orders of magnitude. Cpdll and protonated Cpdll should be able to activate weak $\mathrm{C}-\mathrm{H}$ bonds, such as that of ethylbenzene or related substrates.

\section{Conclusions}

A detailed computational study using density functional theory is presented on the hydrogen atom abstraction ability of various potential oxidants in P450 catalysis, namely Cpdl, Cpdll and protonated Cpdll. The work shows that although $\mathrm{Cpdl}$ is by far the better oxidant of the three, actually, the hydrogen atom abstraction barriers of the other two are only about $5 \mathrm{kcal} \mathrm{mol}^{-1}$ higher in energy. In principle, Cpdll and protonated Cpdll should be able to activate substrates with moderately strong $\mathrm{C}-\mathrm{H}$ bonds but with reaction rates that are orders of magnitude slower than those found for Cpdl. All reaction mechanisms are stepwise with an initial and rate-determining hydrogen atom abstraction followed by a rebound barrier of lower magnitude. With Cpdl as the oxidant, rebound barriers are small, while with Cpdll and protonated Cpdll these are significant, which implies that the hydroxylation of substrates by Cpdll and protonated Cpdll should give considerable amount of by-products originating from stereochemical scrambling or isomerization in agreement with what was experimentally found for their model complexes.

The computational modelling is supported by thermochemical analysis of hydrogen atom abstraction, electron transfer and proton transfer mechanisms that specify the thermochemical properties that determine the rate constant and thermochemistry. Finally, valence bond models for the hydrogen atom abstraction from substrate by Cpdl, Cpdll and protonated Cpdll have been set up that dissect the transition state energies into contributions from the breaking and forming of molecular orbitals and bonds as well as individual electron transfer processes.

\section{Experimental Section}

In order to determine the reactivity differences of Cpdl versus CpdII and protonated Cpdll with substrates and establish what structure will act as a superior oxidant, we carried out extensive density functional theory (DFT) calculations on model complexes. These sets of calculations enable us to characterize the intrinsic chemical features of the oxidant and substrate that drive the reaction mechanism without the perturbations of the protein matrix.

All calculations utilize DFT as implemented in the Gaussian-09 program package. ${ }^{[37]}$ The chemical structure of the P450 active site was modelled using an iron embedded in protoporphyrin IX (Por), whereby all side chains were abbreviated to hydrogen atoms and the cysteinate anion to thiolate, $\left[\mathrm{Fe}(\mathrm{O})\left(\mathrm{Por}^{+*}\right)(\mathrm{SH})\right]^{0}$. This model was shown previously to match larger models as well as QM/MM optimized geometries well. [38] Cpdl (1) and Cpdll (2) had one oxo group in the sixth ligand position and overall charge 0 and -1 , respectively. Cpdl or $\left[\mathrm{Fe}^{\mathrm{IV}}(\mathrm{O})\left(\mathrm{Por}^{+\cdot}\right) \mathrm{SH}\right]^{0}$ was modelled in the lowest lying doublet and quartet spin states, whereas Cpdll or $\left[\mathrm{Fe}^{\mathrm{IV}}(\mathrm{O})(\mathrm{Por}) \mathrm{SH}\right]^{-}$was calculated in the singlet, triplet and quintet spin states. However, as the singlet spin state of Cpdll was $27 \mathrm{kcal} \mathrm{mol}^{-1}$ above the triplet spin state (see Supporting Information), we did not consider its chemical reactivity. Protonated Cpdll $\left(2 \mathrm{H}^{+}\right)$had configuration $\left[\mathrm{Fe}^{\mathrm{IV}}(\mathrm{OH})(\mathrm{Por})(\mathrm{SH})\right]^{0}$ and overall charge zero.

Reactivity patterns of $\mathbf{1}, 2$ and $2 \mathrm{H}^{+}$with model substrates, namely cyclohexane $(\mathrm{CH})$ and ethylbenzene $(\mathrm{EB})$ were calculated with DFT methods. These models were successfully applied in the past and found to reproduce experimentally determined product isotope effects, rate constants and product ratios well. ${ }^{[39]}$

We initially explored the potential energy surface of hydrogen atom abstraction from the substrate by all oxidants through extensive geometry scans at the UB3LYP/BS1 level of theory (BS1 stands for LACVP with core potential on iron/6-31G on the rest of the atoms). ${ }^{[40,41]}$ During the geometry scans one degree of freedom was fixed, but all other degrees of freedom were minimized. Subsequently, all geometries were optimized without constraints and followed by a frequency calculation at the same level of theory. All local minima had real frequencies only, whereas the transition states were characterized by a single imaginary frequency for the correct mode.

To improve the energetics, we ran single point calculations with a triple- $\zeta$ basis set on all atoms: BS2 stands for LACV3P+ on iron (with core potential) and $6-311+G^{*}$ on the rest of the atoms. In addition, solvent single points were performed using the polarized continuum model as implemented in Gaussian-09 with a dielectric constant of $\varepsilon=5.697$ representing a chlorobenzene solution.

To test the effect of the density functional method on the spin-state ordering, relative energies, and regioselectivities of iron(IV)-oxo complexes we recently performed an extensive study on substrate sulfoxidation with a range of density functional theory methods, basis sets and environmental conditions. ${ }^{[42]}$ These studies showed that most DFT methods predict regioselectivities and Hammett plots excellently, but have a systematic error in their calculated enthalpy of activation with respect to experiment. Moreover, it was shown that the entropy is generally overestimated by about $50 \%$. These studies showed that $\mathrm{PBE} 0 / \mathrm{BS} 2 / / \mathrm{PBE} 0 / \mathrm{BS} 1+\mathrm{PCM}$ and B3LYP/BS2//B3LYP/BS1+PCM 
reproduce oxygen atom transfer barriers to within $4 \mathrm{kcal} \mathrm{mol}^{-1}$ of experiment and hence those methods are used here. We also did a ful geometry optimization for one mechanism using UB3LYP/BS2, but as before, ${ }^{[25]}$ the full potential energy surface is close to that obtained at UB3LYP/BS2//UB3LYP/BS1 with energies raised by a few $\mathrm{kcal} \mathrm{mol}^{-1}$.

Kinetic isotope effects were evaluated from data from the frequency calculations, whereby one or more of the hydrogen atoms of the substrate were replaced by deuterium atoms and the vibrational frequencies and entropy re-analyzed. ${ }^{[18]}$ We used the Eyring and Wigner models as described in Eqs $13-15$ to estimate the KIE Eyring and KIEWigner, respectively.

$\mathrm{KIE}_{\text {Eyring }}=\exp \left\{\left(\Delta \mathrm{G}^{ \pm} \mathrm{D}-\Delta \mathrm{G}^{\ddagger_{H}}\right) / \mathrm{RT}\right\}$

$\mathrm{KIEWigner}=\mathrm{KIE}_{\text {Eyring }} \times \mathrm{Q}_{\mathrm{tH}} / \mathrm{QtD}_{\mathrm{tD}}$

$\mathrm{Q}_{\mathrm{t}}=1+\left(\mathrm{h} v / \mathrm{k}_{\mathrm{B}} \mathrm{T}\right)^{2} / 24$

In these equations $R$ is the gas constant, $T$ is the temperature $(298.15 \mathrm{~K})$ $\Delta \mathrm{G}^{\ddagger}$ is the free energy of activation, $\mathrm{h}$ is Planck's constant, $\mathrm{k}_{\mathrm{B}}$ is Boltzmann's constant and $v$ the imaginary frequency in the transition state.

\section{Acknowledgements}

The EU-COST Network Explicit Control Over Spin-states in Technology and Biochemistry (ECOSTBio, CM1305) is acknowledged for support. VP and MS thanks the support of the Ministerio de Economía y Competitividad of Spain (Projects CTQ2014-54306-P and grant No. BES-2012-052801 to VP), Generalitat de Catalunya (project number 2014SGR931, Xarxa de Referència en Química Teòrica i Computacional, and ICREA Academia prizes for MS), and European Fund for Regional Development (FEDER grant UNGI10-4E-801). ASF thanks the Tertiary Education Trust Fund in Nigeria for a studentship.

Keywords: Density functional theory $\bullet$ cytochrome P450 • iron(IV)-oxo $\bullet$ hydroxylation $\bullet$ reactivity

[1] a) M. Sono, M. P. Roach, E. D. Coulter, J. H. Dawson, Chem. Rev. 1996, 96, 2841-2888; b) P. R. Ortiz de Montellano (Ed.), Cytochrome P450: Structure, Mechanism and Biochemistry, 3rd ed., Kluwer Academic/Plenum Publishers, New York, 2005; c) A. W. Munro, H. M. Girvan, K. J. McLean, Nat. Prod. Rep. 2007, 24, 585-609; d) K. M. Kadish, K. M. Smith, R. Guilard (Eds.), Handbook of Porphyrin Science, World Scientific Publishing Co., New Jersey, 2010; e) S. P. de Visser D. Kumar (Eds.), Iron-containing enzymes: Versatile catalysts of hydroxylation reaction in nature, RSC Publishing, Cambridge (UK), 2011; f) G. Grogan, Curr. Opin. Chem. Biol. 2011, 15, 241-248; g) P. R. Ortiz de Montellano, Chem. Rev. 2010, 110, 932-948.

[2] a) F. P. Guengerich, Chem. Res. Toxicol. 2001, 14, 611-650; b) G. H. Posner, P. M. O'Neill, Acc. Chem. Res. 2004, 37, 397-404.

[3] a) Y. Tsuchiya, M. Nakajima, T. Yokoi, Cancer Lett. 2005, 227, 115124; b) B. Krámos, J. Oláh, J. Phys. Chem. B 2014, 118, 390-405.

[4] a) D. R. Nelson, Human Genomics 2009, 4, 59-65; b) J. Mestres, Proteins: Struct., Funct., Bioinf. 2005, 58, 596-609.

[5] A. Wang, C. D. Stout, Q. Zhang, E. F. Johnson, J. Biol. Chem. 2015 , 290, 5092-5104

[6] a) J. H. Dawson, M. Sono, Chem. Rev. 1987, 87, 1255-1276; b) B. Meunier, S. P. de Visser, S. Shaik, Chem. Rev. 2004, 104, 3947-3980; c) I. G. Denisov, T. M. Makris, S. G. Sligar, I. Schlichting, Chem. Rev. 2005, 105, 2253-2277.
[7] a) M. T. Green, J. Am. Chem. Soc. 2000, 122, 9495-9499; b) F Ogliaro, S. P. de Visser, Shimrit Cohen, J. Kaneti, S. Shaik, ChemBioChem. 2001, 2, 848-851.

[8] a) W. Nam, Acc. Chem. Res. 2007, 40, 522-531; b) Y. Watanabe, H. Nakajima, T. Ueno, Acc. Chem. Res. 2007, 40, 554-562.

[9] J. Rittle, M. T. Green, Science 2010, 330, 933-937.

[10] a) S. Shaik, D. Kumar, S. P. de Visser, A. Altun, W. Thiel, Chem. Rev. 2005, 105, 2279-2328; b) M. R. A. Blomberg, T. Borowski, F. Himo, R. Z. Liao, P. E. M. Siegbahn, Chem. Rev. 2014, 114, 3601-3658.

[11] a) M. Zederbauer, P. G. Furtmüller, S. Brogioni, C. Jakopitsch, G Smulevich, C. Obinger, Nat. Prod. Rep. 2007, 24, 571-584; b) P Vidossich, G. Fiorin, M. Alfonso-Prieto, E. Derat, S. Shaik, C. Rovira, J. Phys. Chem. B 2010, 114, 5161-5169; c) B. R. Streit, B. Blanc, G. S. Lukat-Rodgers, K. R. Rodgers, J. L. DuBois, J. Am. Chem. Soc. 2010, 132, 5711-5724; d) R. Davydov, R. L. Osborne, S. H. Kim, J. H. Dawson, B. M. Hoffman, Biochemistry 2008, 47, 5147-5155.

[12] a) H.-P. Hersleth, K. K. Andersson, Biochim. Biophys. Acta 2011, 1814 785-796; b) H.-P. Hersleth, T. Uchida, A. K. Røhr, T. Teschner, V. Schünemann, T. Kitagawa, A. X. Trautwein, C. H. Görbitz, K. K. Andersson, J. Biol. Chem. 2007, 282, 23372-23386; c) A. Gumiero, C. L. Metcalfe, A. R. Pearson, E. L. Raven, P. C. E. Moody, J. Biol. Chem 2011, 286, 1260-1268; d) A. Altun, Comp. Theor. Chem. 2015, 1063 35-41.

[13] a) M. Costas, M. P. Mehn, M. P. Jensen, L. Que Jr, Chem. Rev. 2004 104, 939-986; b) S. V. Kryatov, E. V. Rybak-Akimova, S. Schindler Chem. Rev. 2005, 105, 2175-2226; c) M. M. Abu-Omar, A. Loaiza, N. Hontzeas, Chem. Rev. 2005, 105, 2227-2252; d) P. C. A. Bruijnincx, G. van Koten, R. J. M. Klein Gebbink, Chem. Soc. Rev. 2008, 37, 27162744; e) M. Costas, Coord. Chem. Rev. 2011, 255, 2912-2932; f) A. R. McDonald, L. Que Jr, Coord. Chem. Rev. 2013, 257, 414-428; g) W Nam, Y.-M. Lee, S. Fukuzumi, Acc. Chem. Res. 2014, 47, 1146-1154.

[14] a) C. Fertinger, N. Hessenauer-llicheva, A. Franke, R. van Eldik, Chem. Eur. J. 2009, 15, 13435-13440; b) M. Oszajca, A. DrzewieckaMatuszek, A. Franke, D. Rutkowska-Zbik, M. Brindell, M. Witko, G Stochel, R. van Eldik, Chem. Eur. J. 2014, 20, 2328-2343.

[15] J. T. Groves, Z. Gross, M. K. Stern, Inorg. Chem. 1994, 33, 5065-5072.

[16] Y. J. Jeong, Y. Kang, A.-R. Han, Y.-M. Lee, H. Kotani, S. Fukuzumi, W. Nam, Angew. Chem. Int. Ed. 2008, 47, 7321-7324.

[17] M. Oszajca, A. Franke, A. Drzewiecka-Matuszek, M. Brindell, G Stochel, R. van Eldik, Inorg. Chem. 2014, 53, 2848-2857.

[18] S. P. de Visser, S. Shaik, P. K. Sharma, D. Kumar, W. Thiel, J. Am. Chem. Soc. 2003, 125, 15779-15788.

[19] a) F. Ogliaro, N. Harris, S. Cohen, M. Filatov, S. P. de Visser, S. Shaik, J. Am. Chem. Soc. 2000, 122, 8977-8989; b) S. P. de Visser, F. Ogliaro, P. K. Sharma, S. Shaik, Angew. Chem. Int. Ed. 2002, 41, 1947-1951; Angew. Chem. 2002, 114, 2027-2031; c) S. P. de Visser, J. Am. Chem. Soc. 2006, 128, 15809-15818; d) S. P. de Visser, L. Tahsini, W. Nam, Chem. Eur. J. 2009, 15, 5577-5587; e) R. Latifi, M. A. Sainna, E. V. Rybak-Akimova, S. P. de Visser, Chem. Eur. J. 2013, 19, 4058-4068

[20] S. P. de Visser. Chem. Eur. J. 2006, 12, 8168-8177.

[21] S. P. de Visser, F. Ogliaro, S. Shaik, Angew. Chem. Int. Ed. 2001, 40, 2871-2874; Angew. Chem. 2001, 113, 2955-2958

[22] a) S. P. de Visser, D. Kumar, S. Cohen, R. Shacham, S. Shaik, J. Am. Chem. Soc. 2004, 126, 8362-8363; b) S. Shaik, D. Kumar, S. P. de Visser, J. Am. Chem. Soc. 2008, 130, 10128-10140.

[23] A. Rosa, G. Ricciardi, Inorg. Chem. 2012, 51, 9833-9845.

[24] S. P. de Visser, Adv. Inorg. Chem. 2012, 64, 1-31.

[25] G. S. Hammond, J. Am. Chem. Soc. 1955, 77, 334-338.

[26] a) F. P. Guengerich, D. H. Kim, Chem. Res. Toxicol. 1991, 4, 413-421; b) A. E. Rettie, A. W. Rettenmeier, W. N. Howald, T. A. Baillie, Science 1987, 235, 890-893.

[27] D. Kumar, L. Tahsini, S. P. de Visser, H. Y. Kang, S. J. Kim, W. Nam, J. Phys. Chem. A 2009, 113, 11713-11722.

[28] C. J. Bougher, S. Liu, S. D. Hicks, M. M. Abu-Omar, J. Am. Chem. Soc 2015, 137, 14481-14487.

[29] S. P. de Visser, J. Am. Chem. Soc. 2010, 132, 1087-1097. 
[30] a) A. Ghosh, Acc. Chem. Res. 1998, 31, 189-198; b) M. T. Green, J. Am. Chem. Soc. 1999, 121, 7939-7940; c) M. Radoń, E. Broclawik, K. Pierloot, J. Chem. Theory Comput. 2011, 7, 898-908.

[31] S. P. de Visser, F. Ogliaro, P. K. Sharma, S. Shaik, J. Am. Chem. Soc 2002, 124, 11809-11826.

[32] a) S. S. Shaik, J. Am. Chem. Soc. 1981, 103, 3692-3697; b) S. Shaik, Phys. Chem. Chem. Phys. 2010, 12, 8706-8720.

[33] J. J. Warren, J. M. Mayer, J. Am. Chem. Soc. 2008, 130, 2774-2776.

[34] a) D. Kumar, B. Karamzadeh, G. N. Sastry, S. P. de Visser, J. Am. Chem. Soc. 2010, 132, 7656-7667; b) D. Kumar, G. N. Sastry, S. P. de Visser, Chem. Eur. J. 2011, 17, 6196-6205; c) S. Kumar, A. S. Faponle P. Barman, A. K. Vardhaman, C. V. Sastri, D. Kumar, S. P. de Visser, J. Am. Chem. Soc. 2014, 136, 17102-17115.

[35] M. G. Quesne, D. Senthilnathan, D. Singh, D. Kumar, P. Maldivi, A. B. Sorokin, S. P. de Visser, ACS Catal. 2016, 6, 2230-2243.

[36] a) P. Barman, P. Upadhyay, A. S. Faponle, J. Kumar, S. S. Nag, D. Kumar, C. V. Sastri, S. P. de Visser, Angew. Chem. Int. Ed. 2016, 55, 11091-11095; b) F. G. Cantú Reinhard, M. A. Sainna, P. Upadhyay, G. A. Balan, D. Kumar, S. Fornarini, M. E. Crestoni, S. P. de Visser, Chem. Eur. J. 2016, 22, 18608-18619; c) F. G. Cantú Reinhard, S. P. de Visser, Chem. Eur. J. 2017, 23, 2935-2944.

[37] M. J. Frisch, Gaussian 09, revision D.01; Gaussian, Inc., Wallingford, CT, 2009.

[38] See, e.g., a) J. C. Schöneboom, H. Lin, N. Reuter, W. Thiel, S. Cohen, F. Ogliaro, S. Shaik, J. Am. Chem. Soc. 2002, 124, 8142-8151; b) C. M.
Bathelt, J. Zurek, A. J. Mulholland, J. N. Harvey, J. Am. Chem. Soc. 2005, 127, 12900-12908; c) L. Ji, A. S. Faponle, M. G. Quesne, M. A Sainna, J. Zhang, A. Franke, D. Kumar, R. van Eldik, W. Liu, S. P. de Visser, Chem. Eur. J. 2015, 21, 9083-9092; d) M. G. Quesne, T. Borowski, S. P. de Visser, Chem. Eur. J. 2016, 22, 2562-2581; e) A. S. Faponle, M. G. Quesne, S. P. de Visser, Chem. Eur. J. 2016, 22, 54785483.

[39] a) D. Kumar, R. Latifi, S. Kumar, E. V. Rybak-Akimova, M. A. Sainna, S P. de Visser, Inorg. Chem. 2013, 52, 7968-7979; b) M. A. Sainna, S Kumar, D. Kumar, S. Fornarini, M. E. Crestoni, S. P. de Visser, Chem Sci. 2015, 6, 1516-1529; c) Y. Wang, D. Kumar, C. L. Yang, K. L. Han, S. Shaik, J. Phys. Chem. B 2007, 11, 7700-7710; d) Y. Wang, C. L. Yang, H. M. Wang, K. L. Han, S. Shaik, ChemBioChem. 2007, 8, 277281.

[40] a) A. D. Becke, J. Chem. Phys. 1993, 98, 5648-5652; b) C. Lee, W. Yang, R. G. Parr, Phys. Rev. B 1988, 37, 785-789.

[41] a) P. J. Hay, W. R. Wadt, J. Chem. Phys. 1985, 82, 299-310; b) W. J. Hehre, R. Ditchfield, J. A. Pople, J. Chem. Phys. 1972, 56, 2257-2261.

[42] F. G. Cantú Reinhard, A. S. Faponle, S. P. de Visser, J. Phys. Chem. A 2016, 120, 9805-9814.

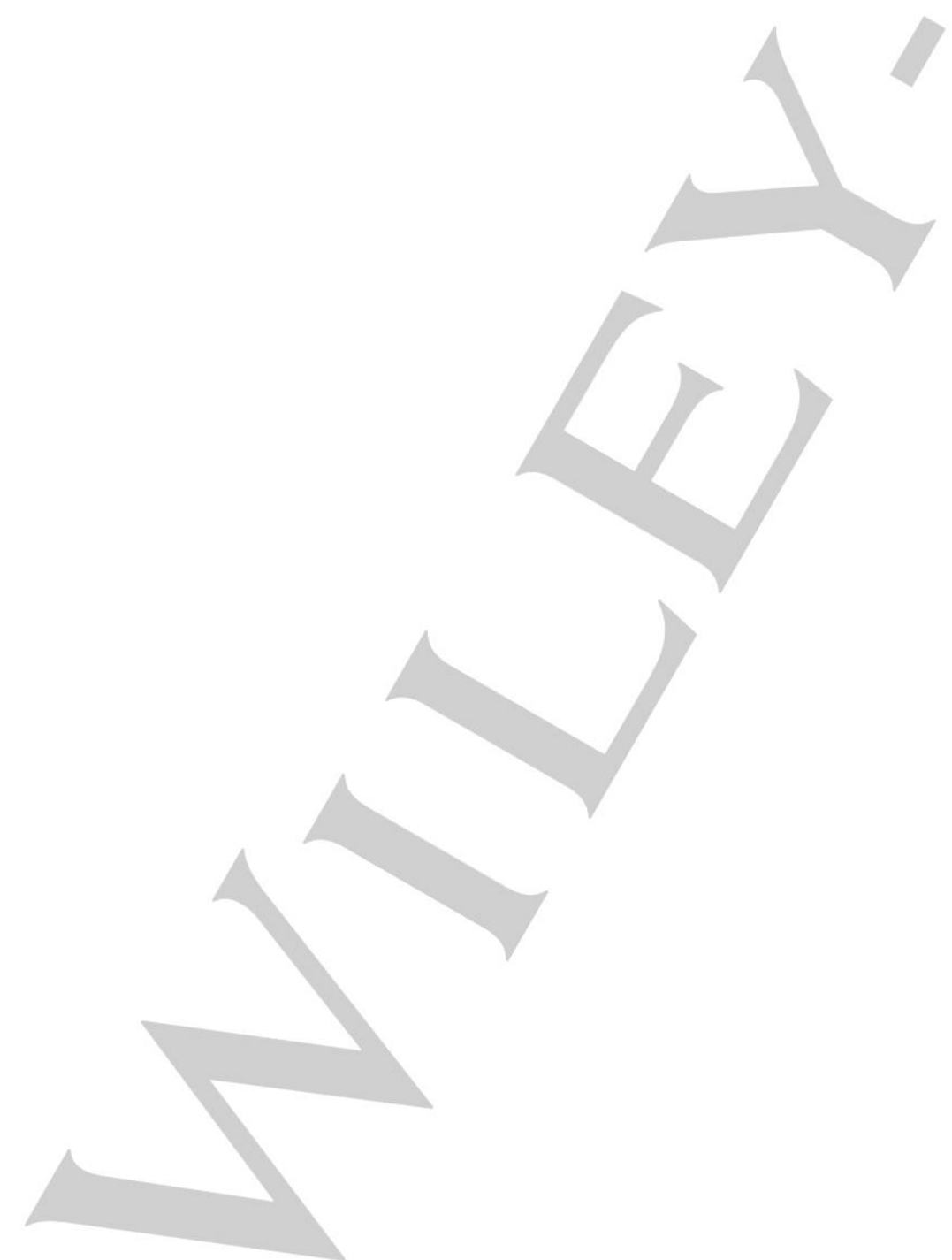


Entry for the Table of Contents (Please choose one layout)

Layout 1:

\section{FULL PAPER}

Text for Table of Contents

Layout 2:

\section{FULL PAPER}

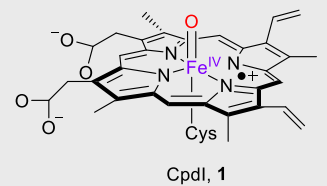

$>>$

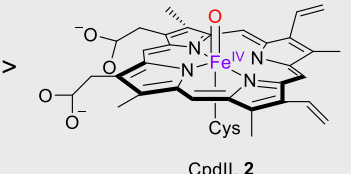

((Insert TOC Graphic here: $\max$. width: $5.5 \mathrm{~cm}$; max. height: $5.0 \mathrm{~cm}$ ))
Author(s), Corresponding Author(s)*

\section{Page No. - Page No.}

Title
Density functional theory modelling on the relative reactivity of Compound I, Compound II and protonated Compound II with respect to aliphatic substrates is presented. We show that Compound I is the preferred oxidant, but Compound II and its protonated form can activate aliphatic $\mathrm{C}-\mathrm{H}$ bonds with reasonable rate

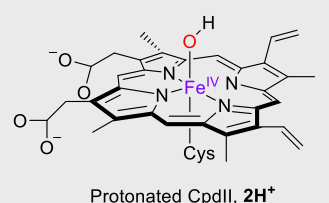

Protonated Cpdll, $2 \mathrm{H}^{+}$ constants. However, they give different product distributions due to stereochemical scrambling.
Xiao-Xi Li, Verònica Postils, Wei Sun, Abayomi S. Faponle, Miquel Solà, Yong Wang, ${ }^{*}$ Wonwoo Nam, ${ }^{*}$ and Sam P. de Visser* $^{*}$

Page No. - Page No.

Reactivity patterns of protonated Compound II and Compound I of Cytochrome P450: What is the better oxidant? 